This item was submitted to Loughborough's Research Repository by the author.

Items in Figshare are protected by copyright, with all rights reserved, unless otherwise indicated.

\title{
Examining real interest parity: which component reverts quickest and in which regime?
}

\section{PLEASE CITE THE PUBLISHED VERSION}

http://dx.doi.org/10.1016/j.irfa.2015.01.007

\section{PUBLISHER}

(C) Elsevier

VERSION

AM (Accepted Manuscript)

\section{PUBLISHER STATEMENT}

This work is made available according to the conditions of the Creative Commons Attribution-NonCommercialNoDerivatives 4.0 International (CC BY-NC-ND 4.0) licence. Full details of this licence are available at: https://creativecommons.org/licenses/by-nc-nd/4.0/

\section{LICENCE}

CC BY-NC-ND 4.0

\section{REPOSITORY RECORD}

Sirichand, Kavita, Andrew J. Vivian, and Mark E. Wohar. 2019. "Examining Real Interest Parity: Which Component Reverts Quickest and in Which Regime?”. figshare. https://hdl.handle.net/2134/16923. 
Examining real interest parity: which component reverts quickest and in which regime?

\begin{abstract}
$\underline{\text { Abstract }}$
This article re-examines real interest parity (RIP), focusing upon which component of real interest parity drives convergence to parity. We find that it is the reversion of inflation rather than nominal interest rates which is the primary source of convergence to RIP. Nominal interest rate differentials are found to be persistent during both periods. Furthermore, we additionally find that mean reversion in the inflation differentials is faster during the Gold Standard period.
\end{abstract}

Keywords: comovement, real interest rate parity, inflation differential, nominal interest rate differential, fisher effect, Gold Standard, floating exchange rate JEL: G10, G15, G30 


\section{INTRODUCTION}

Real interest rate parity is one of the cornerstones of international finance. It states that real interest rates in the domestic country equal real interest rates in the foreign country. While evidence in favour of this theory in this strong form is rather sparse, there is much broader support for a weaker form of the theory that states that real interest rates converge towards real interest rate parity. Nevertheless, there has been remarkably little work investigating which component of the real interest parity condition drives its longer term convergence. Chung and Crowder (2004) note that real interest rate parity is based upon four relationships holding: relative purchasing power parity, uncovered interest rate parity, the Fisher effect in the domestic country and the Fisher effect in the foreign country. Chung and Crowder (2004) provide some initial evidence on whether the four conditions for interest rate parity hold during the post-World War II sample period. They report that evidence indicates that the failure of uncovered interest parity is the dominant factor that leads to the failure of RIP.

In this paper we extend this analysis in two respects. First, we examine separately different exchange rate regimes: the Gold Standard period and the post-Bretton Woods period where floating exchange rate regimes predominate (following Dreger, 2010 for real interest parity). Second, and most importantly, we test which component is most important in driving convergence towards interest rate parity; to be specific we i) estimate the speed of meanreversion for each component of the real parity relationship and ii) examine the extent to which the nominal interest rate differentials and inflation differentials commove with RIP. We note that the difference in real interest rates equals the nominal interest rate differential minus the inflation differential, which also equals the real interest rate in the domestic country minus the real interest rate in the foreign country. Consequently, we examine the 
speed of mean reversion of the inflation differential, the nominal interest rate differential, the real interest rate in the domestic country and the real interest rate in the foreign country.

\section{BACKGROUND - REAL INTEREST PARITY}

Real interest rate parity (RIP) in its strictest form simply states that the expected domestic real interest rate is equal to the expected foreign real interest rate:

$$
E_{t} r_{t, t+1}=E_{t} r_{t, t+1}^{*}
$$

where $E$ is expectations, $t$ denotes the time period, $r$ is the real interest rate and an asterisk denotes the foreign country.

Table 1 presents a summary of the literature on RIP and provides further details on the data span, countries examined and findings. The early literature finds little evidence to support this strict form of RIP (see e.g., Mishkin, 1981, 1984; Cumby and Obstfeld, 1984; Mark, 1985) as shown in Table 1. That is, the equality of real interest rates is rejected.

Subsequent literature has examined a weaker form of RIP that tests if real interest rates converge towards parity. For example, there is some evidence from unit root tests that the real interest rate differential ( $\mathrm{RID}=E_{t} r_{t, t+1}-E_{t} r_{t, t+1}^{*}$ ) is stationary amongst major developed economies (see e.g. Meese and Rogoff, 1988; Cavaglia, 1992; Edison and Pauls, 1993), while UIP is supported in Asian economies (Moosa and Bhatti, 1997). More recent work finds evidence for RIP using cointegation methods amongst developed markets (e.g. Awad and Goodwin, 1998; Wu and Fountas, 2000) and emerging markets (e.g. Chinn and Frankel, 1995; Phylaktis, 1999). Panel unit root techniques offer another way to enhance test power by incorporating cross sectional variation in the panel. The studies using panel data to raise power find strong evidence favouring RIP (e.g.,Wu and Chen, 1998; Holmes, 2002; 
Baharumshah et al., 2005). Holmes (2002) reports that the half-life for adjustment to RIP occurs within several months, while Ferreira and León-Ledesma (2007) note that adjustment to RIP is quicker in emerging markets than in developed markets. Notably, Camarero et al. (2009) tested for RIP using panel unit root and stationarity tests with cross-sectional dependence, and found evidence against RIP among the 19 major OECD countries.

Some literature has attempted to focus on the ex-ante real interest rate more directly by modelling or proxying for expected inflation. Using a VAR, Driffill and Snell (2003) find real ex-ante interest rates respond to nominal shocks. Kandel, Ofer and Sarig (1996) use indexed bonds to infer inflation expectations; their results suggest a negative correlation between ex-ante real interest rates and expected inflation. Neither studies' key result seems consistent with the Fisher hypothesis (or weak-form RIP). Herwartz and Roestel (2011) using inflation indexed bonds find there is convergence of long-term ex ante real interest rates, while prior literature primarily focuses on short-term interest rates; their evidence is consistent with weak-form RIP and supports capital market integration amongst the four major markets they examine.

Another recent branch of literature highlights that structural breaks in RIDs are an important feature that one should take into account in any empirical testing framework (e.g., Fountas and $\mathrm{Wu}, 1999)$. By allowing for structural breaks in unit root tests, Fountas and $\mathrm{Wu}$ (1999) and Arghyrou et al. (2009) find that there is evidence in favour of RIP in the EU member countries.

In this paper we focus on the weaker form of RIP, which considers if real interest rates converge towards parity. The vast majority of prior RIP literature focuses on the post-WWII period. A notable exception is Dreger (2010), who examines different exchange rate regimes including the Gold Standard period. We follow Dreger (2010) by examing the RIP condition in both the post-Bretton Woods era and the Gold Standard period. However, we extend 
Dreger (2010) by decomposing the RIP condition into its separate components in the spirit of Chung and Crowder (2004). We also extend Dreger (2010) and Chung and Crowder (2004), who focus on whether there is convergence by estimating how quickly convergence occurs.

\section{[INSERT TABLE 1:]}

We begin the derivation of RIP by noting that the Fisher equation states that the expected real interest rate equals the nominal interest rate minus expected inflation:

$$
\begin{aligned}
& E_{t} r_{t, t+1}=i_{t, t+1}-E_{t} \pi_{t, t+1} \\
& E_{t} r_{t, t+1}^{*}=i_{t, t+1}^{*}-E_{t} \pi_{t, t+1}^{*}
\end{aligned}
$$

We then subtract the domestic Fisher equation from the foreign Fisher equation:

$$
\begin{aligned}
& E_{t} r_{t, t+1}-E_{t} r_{t, t+1}^{*}=i_{t, t+1}-i_{t, t+1}^{*}-\left[E_{t} \pi_{t, t+1}-E_{t} \pi_{t, t+1}^{*}\right] \\
& E_{t} r_{t, t+1}-E_{t} r_{t, t+1}^{*}=i_{t, t+1}-E_{t} \pi_{t, t+1}-\left[i_{t, t+1}^{*}-E_{t} \pi_{t, t+1}^{*}\right]
\end{aligned}
$$

Our study focuses on these two equations, (4) and (5); on the left-hand side is the real interest rate differential ( $\mathrm{RID}=E_{t} r_{t, t+1}-E_{t} r_{t, t+1}^{*}$ ). Equation (4) states that RID is comprised of two different components; the first is the nominal interest rate differential between the domestic and foreign market, and the second is the inflation differential between the domestic and foreign market. This paper examines which of these two component of the real interest rate differential drives convergence towards real interest rate parity. Is convergence driven by the nominal interest rate differential or the inflation differential?

Equation (5) states that the difference in real interest rates can also be decomposed into two other components. First, the nominal interest rate minus expected inflation in the domestic country and second, the nominal interest rate minus expected inflation in the foreign country. Our main new research inquiries are to: i) to examine if the speed of convergence differs between the Gold Standard period and the post-Bretton Woods era, ii) examine how 
quickly, if at all, each component of RIP converges and iii) analyse the comovement of RIP with nominal interest rate different differentials and inflation differentials.

\section{METHODOLOGY}

To investigate how quickly each component of RIP converges we examine a typical $\mathrm{AR}(1)$ regression:

$$
y_{i t+1}=\alpha+\beta_{i} y_{i t}+\varepsilon_{i t+1}
$$

where $y_{i t+1}$ is the deviation from real interest rate parity or a component of real interest parity. If there is no convergence towards parity in the long term then $\beta$ will equal 1 . If $\beta$ is less than 1 (but greater than -1) then there is convergence to parity in the long term. If $\beta$ is 0 then this indicates that there is full adjustment towards parity in one period.

To examine the comovement between the RIP and its component parts, the nominal interest rate differential and the inflation differential, we use a method proposed by Yetman (2011) that provides a measure of comovement at time $t$ between two series $x$ and $y$, computed as the product of their respective $z$-scores: ${ }^{1}$

$$
\rho_{t}^{x y}=\frac{\left(x_{t}-\bar{x}\right)}{\sqrt{\frac{1}{T-1} \sum_{t=1}^{T}\left(x_{t}-\bar{x}\right)^{2}}} \cdot \frac{\left(y_{t}-\bar{y}\right)}{\sqrt{\frac{1}{T-1} \sum_{t=1}^{T}\left(y_{t}-\bar{y}\right)^{2}}}=z_{x t} z_{y t}
$$

This provides a dynamic measure of comovement and allows us to establish the extent of any comovement and examine how this comovement may have evolved through time, as such, we

\footnotetext{
${ }^{1}$ As Yetman (2011) points out, up to one-degree of freedom correction, the average of the comovements in each time period as given by Equation (7) will equal the Pearson Correlation Coefficient, i.e. $\frac{1}{T} \sum_{t=1}^{T} \rho_{t}^{x y}=\frac{T-1}{T} \rho^{x y}$
} 
construct $\rho_{t}^{x y}$ for RIP with both nominal interest rate differentials and inflation differentials for each country. ${ }^{2}$

\section{DATA}

We use the annual dataset on nominal interest rates and inflation for 15 countries compiled by Dreger (2010). The dataset covers the G7 countries as well as some small open economies such as Denmark and the Netherlands. In particular, the countries examined are Australia, Belgium, Canada, Denmark, France, Germany, Italy, Japan, the Netherlands, Norway, Portugal, Spain, Sweden, the UK and US. It is taken from Global Financial Data (GFD) database prior to 1950 and afterwards from World Market Monitor of Global Insight. We focus on two regime periods: the Gold Standard (1870-1914) and the managed float (1973-2006). We focus on these two periods for which there is sufficient data to conduct empirical analysis on each series. In the analysis conducted we take the US to be the domestic, benchmark market and the remaining 14 countries to be the foreign markets. As such, the analysis examines each foreign market's currency and interest rates relative to the US.

[INSERT TABLE 2:]

\section{EVIDENCE ON CONVERGENCE TOWARDS REAL INTEREST PARITY}

The empirical analysis begins by examining, in a global context, whether there is convergence towards RIP in the long-term. There is mounting evidence on this for the recent post-WWII sample, however, there is relatively little evidence for the Gold Standard period. A notable exception is Dreger (2010), who provides evidence of convergence to RIP during the pre WW1 period using panel unit root tests. In contrast to Dreger (2010) we examine RIP

\footnotetext{
${ }^{2}$ Positive values of $\rho_{t}^{x y}$ imply comovement, i.e. $x_{t}$ and $y_{t}$ are either both positive or both negative; whereas, a negative value of $\rho_{t}^{x y}$ implies movement in opposite directions. The relative size of $\rho_{t}^{x y}$ is indicative of the extent of the comovement.
} 
for each country and crucially we examine: i) the speed of convergence towards RIP and ii) comovement of RIP and its components. In subsequent analysis we consider the components of RIP, which are not covered by Dreger (2010).

\section{[INSERT TABLE 3:]}

Table 3 Panel A presents the relationship between the current (annual) real interest rate differential and lagged (annual) real interest rate differential during the Gold Standard period. These results provide clear support that there is convergence towards RIP during the Gold Standard period.

Table 3 Panel B reports results for the managed float period (1973-2006). This enables us to examine if in international markets the convergence towards RIP is relatively unaffected by changes in exchange rate regime. We find convergence to RIP during the managed float period. Intriguingly, the speed of adjustment towards RIP is generally much weaker during the managed float period compared to the Gold Standard period.

The key findings thus far are as follows. Firstly, there is convergence towards RIP in the long run. Secondly, we find that convergence to RIP is much quicker during the Gold standard period than during the managed float period.

One major goal of this paper is to shed more light upon the drivers of the convergence towards RIP; this issue is not considered in most prior literature. It could be that nominal interest rates are driving this phenomenon; however, it is also possible that inflation or meanreverting real interest rates in each country are driving this behavior.

\section{THE DRIVERS OF REAL INTEREST PARITY CONVERGENCE}

In this section we examine which component of RIP is driving its convergence. An AR regression, Equation 6, is estimated for nominal interest rate differentials and inflation 
differentials separately, over both the Gold Standard and managed float periods, to examine which component of RIP is generating the convergence.

Figure 1 plots the nominal interest rate parity and inflation differentials for each market over the Gold Standard and the managed float period. From a visual inspection, it is apparent that inflation is far more volatile in the Gold Standard period relative to both nominal interest rates and itself in the managed float period. This high volatility is likely due to the Gold Standard being a fixed exchange rate and hence only prices could adjust, leading to higher inflation volatility. Therefore it may not be surprising that nominal interest rates are more volatile than inflation during the float period.

Table 4 provides AR regression results for nominal interest rate differentials, with the aim being to examine if the adjustment towards RIP is driven by nominal interest rates. The evidence presented in Table 4 does not support this. In Table 4 Panel A we examine the Gold Standard period; we note that nominal interest rate differentials are relatively persistent and not necessarily significantly different from 1 . These results contrast with those for RIP from Table 3, where in almost all cases the hypothesis of no adjustment $(\beta=1)$ could be rejected.

\section{[INSERT TABLE 4:]}

Table 4 Panel B provides results for the managed float period. Again there is little statistically significant evidence that nominal interest rate differentials converge in the longer term. The coefficient $\beta$ is not statistically significantly different from 1 in the majority of countries at the 5\% level. Both Panel A and Panel B of Table 4 indicate that nominal interest rates are highly persistent. Furthermore, they suggest that the persistence of nominal interest rate differentials are broadly similar during both sub-periods, i.e. during the Gold Standard period and the managed float period.

Table 5 details the speed of adjustment of inflation differentials. Panel A reports results for the Gold Standard period. The results suggest that the inflation differentials adjust very 
rapidly. In fact, in the majority of cases we cannot reject that the $\beta$ coefficient is equal to 0 ; this implies we cannot reject there being full adjustment within one year (one period). This speed of adjustment is much quicker than we reported for RIP in Table 3, suggesting the inflation differentials are the main source of adjustment towards RIP. These results are clearly in sync with Figure 1, where during the Gold Standard period inflation fluctuated considerably in almost all countries in contrast to nominal interest rates.

\section{[INSERT TABLE 5 AND FIGURE 1:]}

Table 5 Panel B reports results for the 1973-2006 managed float sub-sample. These results also indicate there is reversion in inflation differentials. The speed of adjustment is slower than that reported for the Gold Standard sub-sample in Panel A. This might be because during the floating regime the exchange rates could adjust to reduced price differentials between countries and is therefore not dependent upon inflation to bring about the adjustment. Further, policymakers might prefer exchange rate adjustment since inflation adjustment can be costly. In contrast, during the Gold standard period there was effectively a fixed exchange rate, which meant that any adjustment in price levels would be via inflation since the exchange rate could not adjust. As before, these results are consistent with Figure 1. There is more fluctuation in nominal interest parity during the floating period, but less fluctuation in inflation differentials during this later period.

\section{[INSERT TABLE 6:]}

Table 6 reports results for the speed of adjustment of real interest rates in each country. Panel A reports results for the Gold Standard period and Panel B for the managed float period. These results suggest real interest rates do mean-revert in each country. However, they also suggest that US real interest rates are more persistent than for many other countries. This persistence may be a reflection of the fact that US government securities are a major reserve 
asset held by many other sovereign nations and by many investment groups worldwide. This substantial global demand for US securities slows their speed of adjustment.

The results in Table 6 demonstrate that while there is reversion in real interest rates in each country, these are generally more persistent than the inflation differentials reported in Table 5. Consequently, it appears inflation differentials are the most important single source of convergence towards RIP.

\section{[INSERT TABLE 7 AND FIGURE 2]}

Table 7 and Figure 2 report the results for the comovement between the RIP and the nominal interest rate differentials and inflation differentials respectively. Table 7 presents the descriptive statistics for both pairwise comovements with a distinction made between the Gold Standard and the float period, and Figure 2 illustrates how these comovements have evolved through time over both periods.

We find, not surprisingly given Equation 4, that the comovement between RIP and nominal interest rate differentials is generally positive, whilst that between RIP and the inflation differentials is negative, suggesting large movements in opposite directions. In absolute terms, the degree of comovement is greater between RIP and the inflation differentials, shown both by Figure 2 and Table 7, indicating as before that the inflation differentials are the key drivers of convergence towards RIP.

Notably, from Figure 2 and the average comovement values in Table 7, it can be seen that during the Gold Standard period the magnitude of the comovement between RIP and the inflation differentials is greater than that observed for the managed float period. Whereas similar comovement between RIP and the nominal interest rate differential is observed in both periods. This corroborates earlier findings, as presented in Figure 1 and Tables 4 to 6, of large fluctuations in inflation during this period with rapid adjustments in inflation differentials. This can be explained by the pressure on inflation to adjust to reduce price 
differentials given the fixed exchange rate. During the managed float period the exchange rate was free to adjust, thus easing the pressure on inflation, hence in Figure 2 we observe comovements for nominal interest rate differentials and inflation differentials each with the RIP of similar magnitude.

The empirical results provide important evidence on the source of convergence towards RIP. Here we estimated the speed of adjustment of three possible factors: nominal interest differentials, inflation differentials and each countries' real interest rate. Empirical results clearly indicate that inflation differentials are the quickest component to adjust and comove to a greater extent with RIP, while nominal interest rate differentials adjust sluggishly and comove with RIP to a lesser extent.

\section{CONCLUSION}

This article provides new insights on the RIP relationship by i) examining the speed of adjustment towards RIP, ii) examining which component drives adjustment towards RIP and iii) by examining RIP during different exchange rate regimes. First, we find there is adjustment towards RIP in the long run. Second, and importantly, we find that this is driven by reversion in inflation differentials and not by reversion in nominal interest rates.

Finally, we examine if reversion of RIP and its components is dependent upon the exchange rate regime and time period studied. Interestingly, we find that inflation differentials drive convergence towards RIP in both sub-periods; however, inflation differentials converge more rapidly and comove with RIP to a greater extent during the Gold Standard period rather than the recent managed float. During a fixed exchange rate regime, such as the Gold Standard, inflation is the primary mechanism by which price levels across countries can become more aligned. By contrast, during floating regimes both inflation and the exchange rate can adjust which reduces the pressure on inflation to adjust. The speed of 
adjustment of inflation may also partly reflect the fact that inflation differentials were more volatile during the Gold Standard period; it is plausible that smaller deviations frictions like menu costs could inhibit convergence. More generally, our empirical results underline that one should not tacitly assume that convergence towards RIP is through rapid adjustment of nominal interest rates.

This paper provides important evidence that distinguishes between the different drivers of convergence towards RIP in the long term. Our evidence is that inflation differentials adjust much more quickly than nominal interest rates and comove more strongly with RIP; hence it is inflation that drives convergence towards RIP. This result has two important implications. First, if convergence towards RIP is driven by inflation rather than the financial markets then using RIP to gauge the degree of capital market integration for a country (see e.g. Phylaktis, 1999 and Alexakis et al., 1997) would appear to have serious shortcomings. Second, it suggests that nominal interest rates converge slowly; it therefore suggests that central banks can and do follow at least partially independent monetary policies (Mark, 1985). We also find that the speed of convergence of inflation differentials differs across the two exchange rate regimes we consider. During the Gold Standard period inflation was much less persistent than during the managed float period. Consequently, we report that overall convergence towards RIP was much quicker during the Gold Standard period than the recent post-Bretton Woods sample. 


\section{REFERENCES}

Alexakis, P., Apergis, N., and Xanthakis, E., 1997. Integration of international capital markets: further evidence from EMS and non-EMS membership. Journal of International Financial Markets, Institutions and Money, Vol. 7 (3), pp. 277-287.

Arghyrou, M.G., Gregoriou, A., and Kontonikas, A., 2009. Do real interest rate converge? Evidence from the European Union. Journal of International Financial Markets, Institutions and Money, Vol. 19 (3), pp. 447-460.

Awad, M. A. and Goodwin, B. K. (1998). 'Dynamic linkages among real interest rates in international capital markets’, Journal of International Money and Finance, 17, pp. 881-907.

Baharumshah, A. Z, Haw, C. T., Fountas, S., 2005. A panel study on real interest rate parity in East Asian countries: pre and post-liberalization era. Global Finance Journal, Vol. 16(1), 69-85.

Camarero, M., Carrion-i-Silvestre, J.L., Tamarit, C., 2009. Testing for real interest rate parity using panel stationarity tests with dependence: a note. The Manchester School Vol. 77 (1), 112-126.

S. Young Chung and William J. Crowder (2004), "Why Are Real Interest Rates Not Equalized Internationally?”, Southern Economic Journal, Vol. 71, No. 2, pp. 441-458.

Cavaglia, S., 1992. The persistence of real interest differentials: A Kalman filtering approach. Journal of Monetary Economics, Vol. 29 (3), pp. 429-443.

Chinn, M. D., \& Frankel, J. A., 1995. Who drives real interest rates around the Pacific Rim: the USA or Japan? Journal of International Money and Finance, Vol. 14(6), pp. 801-821.

Cumby R.E. and M. Obstfeld, 1984, "International interest-rate and price-level linkages under flexible exchange rates: A review of recent evidence”, in FO Bilson, R Marston (Eds.), "Exchange Rate: Theory and Practice,” NBER books, National Bureau of Economic Research, Inc.

Dreger C., (2010), “Does the nominal exchange rate regime affect the real interest parity condition?” The North American Journal of Economics and Finance, Vol. 21, No. 3, pp. 274-285

Driffill, J. and Snell, A. (2003) What Moves OECD Real Interest Rates?, Journal of Money, Credit and Banking, Vol. 35 (3), pp. 375 - 402.

Edison, H. J. and Pauls, B. D. (1993) A re-assessment of the relationship between real exchange rates and real interest rates: 1974-1990, Journal of Monetary Economics, 31, 165-87.

Ferreira, A. L., and León-Ledesma, M. A., 2007. Does the real interest parity hypothesis hold?

Evidence for developed and emerging markets. Journal of International Money and Finance, Vol. 26

(3), pp. 364-382.

Fountas, S., and Wu, J.-L., 1999. Testing for real interest rate convergence in European countries. Scottish Journal of Political Economy, Vol. 46 (2), pp. 158-174.

Herwartz, H. and Roestel, J., (2011) Convergence of Real Capital Market Interest Rates - Evidence from inflation Indexed Bonds, Journal of Money Credit and Banking, Vol. 43 (7), pp1523 1541.

Holmes, M. J. (2002). 'Does long-run real interest parity hold among EU countries? Some new panel data evidence’, Quarterly Review of Economics and Finance, 42, pp. 733-46.

Kandel, S., Ofer, A.R. and Sarig, O., (1996) Real Interest Rate and Inflation: An Ex-Ante Empirical Analysis. Journal of Finance, Vol. 51 (1), pp. 205 - 225.

Mark, N.C., 1985. Some evidence on the international inequality of real interest rates. Journal of International Money and Finance, Vol. 4 (2), pp. 189-208. 
Meese, R. and Rogoff, K. (1988). 'Was it real? The exchange rate-interest differential relation over the modern floating-rate period', Journal of Finance, 43, pp. 933-48.

Mishkin, F. S. (1981). The real interest rate: An empirical investigation, Carnegie-Rochester Conference Series on Public Policy 15(1): pp. 151-200.

Mishkin, F. S. (1984). 'Are real interest rates equal across countries? An empirical investigation of international parity conditions', Journal of Finance, 39, pp. 1345-57.

Moosa, I.A., \& Bhatti, R.H., 1997. Are Asian markets integrated? Evidence for six countries vis-à-vis Japan. International Economic Journal, Vol. 11, pp. 51-67.

Phylaktis, K., 1999. Capital market integration in the Pacific basin region: an impulse response analysis. Journal of International Money and Finance, Vol. 18 (2), pp. 267-287.

Wu, J. L., and Chen, S. L. (1998). A re-examination of real interest rate parity. Canadian Journal of Economics, pp. 837-851.

Wu, J. L., and Fountas, S. (2000). Real interest rate parity under regime shifts and implications for monetary policy. The Manchester School, Vol. 68, 685-700.

Yetman, J., 2011. Exporting recessions: International links and the business cycle. Economics Letters, Vol. 110 (1), pp. 12-14. 


\begin{tabular}{|c|c|c|c|c|}
\hline \multicolumn{5}{|c|}{$\begin{array}{c}\text { TABLE } 1 \\
\text { Summary of Literature }\end{array}$} \\
\hline Study & Period & Countries & Method + Test Approach & Main Results \\
\hline Mishkin (1981) & $\begin{array}{l}\text { 1953Q1- } \\
1979 Q 4\end{array}$ & US & $\begin{array}{l}\text { Simple regression; } \\
\text { Correlation }\end{array}$ & $\begin{array}{l}\text { Rejects that the real interest rate is constant. Also finds that movements in nominal interest } \\
\text { rates are not a reliable indicator of movements in real rates. }\end{array}$ \\
\hline Mishkin (1984) & $\begin{array}{l}\text { 1967Q2- } \\
1979 Q 2\end{array}$ & $\begin{array}{l}7 \text { Developed } \\
\text { Markets (US, Canada, UK, } \\
\text { France, West Germany, } \\
\text { Netherlands and } \\
\text { Switzerland). }\end{array}$ & $\begin{array}{l}\text { Simple regression; Tests } \\
\text { equality of real interest } \\
\text { rates }\end{array}$ & $\begin{array}{l}\text { Little support for equality of real interest rates. } \\
\text { Suggests this could be due to risk premiums in the forward exchange market rather than } \\
\text { irrationality or unexploited profit opportunities. }\end{array}$ \\
\hline $\begin{array}{l}\text { Cumby and Obstfeld } \\
\text { (1984) }\end{array}$ & $\begin{array}{l}\text { 1976M1- } \\
1981 \mathrm{M} 9\end{array}$ & $\begin{array}{l}6 \text { Developed Markets (US, } \\
\text { UK, Germany, } \\
\text { Switzerland, Canada and } \\
\text { Japan) }\end{array}$ & $\begin{array}{l}\text { Simple regression; Tests of } \\
\text { homoscedastic forecast } \\
\text { errors. }\end{array}$ & $\begin{array}{l}\text { Little support for equality of real interest rates. } \\
\text { Inflation and exchange rate forecast errors are conditionally heteroscedastic. }\end{array}$ \\
\hline Mark (1985) & $\begin{array}{l}1973 \mathrm{M} 5- \\
1982 \mathrm{M} 2\end{array}$ & $\begin{array}{l}7 \text { Developed Markets (US, } \\
\text { Canada, Germany, Italy, } \\
\text { Netherlands and UK) }\end{array}$ & Simple regression & $\begin{array}{l}\text { Very little support for equality of real interest rates net of tax. Limited support for equality of } \\
\text { real interest rates after tax. }\end{array}$ \\
\hline $\begin{array}{l}\text { Meese and Rogoff } \\
\text { (1988) }\end{array}$ & $\begin{array}{l}\text { 1974M2- } \\
1986 \mathrm{M} 3\end{array}$ & $\begin{array}{l}4 \text { Developed Markets (US, } \\
\text { Germany, Japan and UK) }\end{array}$ & $\begin{array}{l}\text { Simple regression; } \\
\text { Unit Root Test. }\end{array}$ & $\begin{array}{l}\text { First, the data do not indicate a strong correspondence between real interest rate differentials } \\
\text { (short-term or long-term) and real exchange rates. } \\
\text { Second, some evidence of a unit root in long-term (but not short-term) real interest } \\
\text { differentials. Thus short-term interest rates appear to converge towards RIP but not long-term } \\
\text { interest rates. }\end{array}$ \\
\hline Cavaglia (1992) & $\begin{array}{l}\text { 1973M1- } \\
1987 \mathrm{M} 12\end{array}$ & $\begin{array}{l}\text { 4 Developed Markets } \\
\text { (US, Germany, } \\
\text { Switzerland and } \\
\text { Netherlands) }\end{array}$ & $\begin{array}{l}\text { State Space Model with } \\
\text { Kalman Filter }\end{array}$ & $\begin{array}{l}\text { Supports convergence of RIDs. Ex-ante real interest differentials for the period } 1973-1987 \text { are } \\
\text { found to be relatively short-lived and mean-reverting to zero. }\end{array}$ \\
\hline $\begin{array}{l}\text { Edison and Pauls } \\
\text { (1993) }\end{array}$ & $\begin{array}{l}\text { 1974Q1- } \\
\text { 1990Q4 }\end{array}$ & $\begin{array}{l}\text { Major Developed } \\
\text { Markets (US, Japan, } \\
\text { Germany, UK, Canada, G- } \\
\text { 10) }\end{array}$ & $\begin{array}{l}\text { Unit Root Test; } \\
\text { Cointegration }\end{array}$ & $\begin{array}{l}\text { Little evidence of mean reversion in real interest differential. } \\
\text { The respective real exchange rates and real interest rates, and most of their constituent series, } \\
\text { are nonstationary. Further, interest rates are not cointegrated with exchange rates. }\end{array}$ \\
\hline $\begin{array}{l}\text { Chinn and Frankel } \\
\text { (1995) }\end{array}$ & $\begin{array}{l}\text { 1982Q3- } \\
\text { 1992Q1 }\end{array}$ & $\begin{array}{l}\text { Pacific Rim countries } \\
\text { (Hong Kong, Malaysia, } \\
\text { Taiwan, Korea, Thailand } \\
\text { and Singapore; Japan and } \\
\text { US base countries) }\end{array}$ & Stochastic Cointegration & $\begin{array}{l}\text { RIP is supported for most Pacific Rim countries. Hong Kong, Malaysia and Taiwan are linked with } \\
\text { both the USA and Japan (in terms of cointegration and positive covariation), while only } \\
\text { Singapore is solely linked with the USA. On the other hand Korea, and perhaps Indonesia and } \\
\text { Thailand appear to be more closely linked with Japan. Real interest parity holds for only the } \\
\text { following interest rate pairs: USA-Singapore, USA-Taiwan and Japan-Taiwan. }\end{array}$ \\
\hline $\begin{array}{l}\text { Kandel, Ofer and Sarig } \\
\text { (1996) }\end{array}$ & $\begin{array}{l}\text { 1984M9- } \\
\text { 1992M3 }\end{array}$ & Israel & $\begin{array}{l}\text { Unit Root Test and Simple } \\
\text { regression }\end{array}$ & $\begin{array}{l}\text { Use indexed bonds and nominal bonds to infer inflation expectations. Results suggest a negative } \\
\text { correlation between ex-ante real interest rates and expected inflation contrary to the Fisher } \\
\text { hypothesis, which predicts a positive correlation. }\end{array}$ \\
\hline $\begin{array}{l}\text { Moosa and Bhatti } \\
\text { (1997) }\end{array}$ & $1980-1994$ & Asian economies & Test UIP and ex-ante PPP. & Find strong support for both UIP and ex-ante PPP in almost all cases. \\
\hline
\end{tabular}




\begin{tabular}{|c|c|c|c|c|}
\hline $\begin{array}{l}\text { Awad and Goodwin } \\
(1998)\end{array}$ & $\begin{array}{l}\text { 1976-1994 } \\
\text { (Weekly) }\end{array}$ & G10 countries & Cointegration & Support convergence towards RIP, especially in the long run. US appears to play a leading role. \\
\hline Wu and Chen (1998) & $\begin{array}{l}\text { 1979M1- } \\
\text { 1996M9 }\end{array}$ & Euro money market & Panel Unit Root & $\begin{array}{l}\text { Strong evidence rejecting null of equality of real interest rates. Support for mean-reversion in } \\
\text { RIDs. }\end{array}$ \\
\hline Phylaktis (1999) & $\begin{array}{l}\text { At most } \\
\text { 1973M8- } \\
\text { 1993M9; } \\
\text { depends on } \\
\text { country }\end{array}$ & Pacific Basin countries & $\begin{array}{l}\text { Cointegration; Impulse } \\
\text { Response Functions (IRFs) }\end{array}$ & $\begin{array}{l}\text { Support long run comovement in real interest rates. Pacific-Basin countries are also more } \\
\text { closely linked with Japan than US. }\end{array}$ \\
\hline Wu and Fountas (2000) & 1974-1995 & G7 against US & $\begin{array}{l}\text { Cointegration allowing for } \\
\text { endogenous structural } \\
\text { change }\end{array}$ & $\begin{array}{l}\text { Their evidence in favour of run co-movement in real interest rates both in the long-run and in } \\
\text { the short-run. The short run results contrast sharply with the lack of RIP suggested by the } \\
\text { traditional econometric methodology that doesn't account for structural breaks. }\end{array}$ \\
\hline Holmes (2002) & 1979-1998 & $\begin{array}{l}\text { Major European Union } \\
\text { countries }\end{array}$ & $\begin{array}{l}\text { Univariate ADF; Panel unit } \\
\text { root test }\end{array}$ & $\begin{array}{l}\text { Strong evidence of "onshore RIP" during } 1986-1990 \text { and } 1993-1998 \text {, but no evidence of RIP } \\
\text { during 1990-1992. During periods where convergence towards RIP is found the estimated half- } \\
\text { life for adjustment is rapid at 2-3 months. }\end{array}$ \\
\hline Drifill and Snell (2003) & $\begin{array}{l}\text { 1957Q1- } \\
\text { 1994Q4 }\end{array}$ & $\begin{array}{l}\text { Five industrialized } \\
\text { nations }\end{array}$ & $\begin{array}{l}\text { Vector Autoregression } \\
\text { (VAR) }\end{array}$ & $\begin{array}{l}\text { Examine the extent to which real ex-ante interest rates respond to nominal and to real shocks } \\
\text { using a VAR model for } 5 \text { major economies. Their analysis suggests an important role for nominal } \\
\text { shocks especially during the 1980s. }\end{array}$ \\
\hline $\begin{array}{l}\text { Chung and Crowder } \\
(2004)\end{array}$ & 1960-1996 & $\begin{array}{l}\text { Five industrialized } \\
\text { nations }\end{array}$ & $\begin{array}{l}\text { Tests the components of } \\
\text { RIP. }\end{array}$ & $\begin{array}{l}\text { Do not support RIP. Examine the components of RIP to examine what causes the rejection of } \\
\text { RIP. No single violation can explain the failure of RIP in all cases. }\end{array}$ \\
\hline $\begin{array}{l}\text { Ferreira and León- } \\
\text { Ledesma (2007) }\end{array}$ & $\begin{array}{l}\text { Different } \\
\text { ranges for } \\
\text { different } \\
\text { countries }\end{array}$ & $\begin{array}{l}\text { Developed and Emerging } \\
\text { Markets }\end{array}$ & Unit Root Test of RIDs. & $\begin{array}{l}\text { Convergence towards RIP is quicker in emerging markets (half-life c. } 4 \text { months) compared to } \\
\text { developed markets (half-life c. } 11 \text { months). }\end{array}$ \\
\hline Camarero et al. (2009) & $\begin{array}{l}\text { 1978Q1- } \\
2006 Q 1\end{array}$ & 19 Major OECD countries & $\begin{array}{l}\text { Panel Unit Root and Panel } \\
\text { Stationarity Tests. Allow } \\
\text { for cross-sectional } \\
\text { dependence. }\end{array}$ & $\begin{array}{l}\text { Evidence against convergence to RIP. They find that one of the common factors in real interest } \\
\text { rate differentials is non-stationary. }\end{array}$ \\
\hline Arghyrou et al. (2009) & $1996-2005$ & 25 EU countries & $\begin{array}{l}\text { Standard ADF. Allow for } \\
\text { structural breaks. }\end{array}$ & $\begin{array}{l}\text { Generally RIDs converge. However, convergence of RIDs is gradual and the speed of } \\
\text { convergence depends upon how structural breaks are modelled. }\end{array}$ \\
\hline Dreger (2010) & $1870-2006$ & 14 developed countries & $\begin{array}{l}\text { Panel Unit Root Test; Test } \\
\text { if all real interest rates } \\
\text { have a unit root. }\end{array}$ & $\begin{array}{l}\text { Across different exchange rate regimes, the null hypothesis of all countries RID's following a unit } \\
\text { root can be rejected. }\end{array}$ \\
\hline $\begin{array}{l}\text { Herwartz and Roestel } \\
\text { (2011) }\end{array}$ & $\begin{array}{l}\text { 2000M1- } \\
2010 \mathrm{M} 1\end{array}$ & $\begin{array}{l}4 \text { Developed Markets } \\
\text { (Canada, France, UK and } \\
\text { US) }\end{array}$ & $\begin{array}{l}\text { Unit Root Test; } \\
\text { Cointegration }\end{array}$ & $\begin{array}{l}\text { Use inflation indexed bonds to examine if there is convergence of long-term ex ante real } \\
\text { interest rates, while prior literature primarily focuses on short-term interest rates. RIDs are } \\
\text { stationary and there is bivariate cointegration in all long-term RIR's examined. This evidence } \\
\text { supports capital market integration amongst the major markets they examine. }\end{array}$ \\
\hline
\end{tabular}


TABLE 2

Descriptive Statistics

\begin{tabular}{|c|c|c|c|c|c|c|c|c|c|}
\hline & & \multicolumn{4}{|c|}{ 1872-1914 } & \multicolumn{4}{|c|}{ 1973-2006 } \\
\hline & & RIP & $i-i^{*}$ & $\pi-\pi^{*}$ & $i-\pi$ & $R I P$ & $i-i^{*}$ & $\pi-\pi^{*}$ & $i-\pi$ \\
\hline \multirow[t]{2}{*}{ AUSTRALIA } & Mean & 26.68 & 31.45 & 4.77 & 345.39 & 27.20 & 169.24 & 142.05 & 348.47 \\
\hline & $\mathrm{SD}$ & 494.23 & 55.48 & 480.52 & 443.70 & 211.57 & 157.18 & 276.64 & 349.20 \\
\hline \multirow[t]{2}{*}{ BELGIUM } & Mean & 27.48 & -18.98 & -46.46 & 346.19 & 67.29 & 9.86 & -57.43 & 388.56 \\
\hline & $\mathrm{SD}$ & 534.43 & 55.01 & 515.49 & 484.62 & 216.42 & 86.39 & 221.68 & 253.91 \\
\hline \multirow[t]{2}{*}{ CANADA } & Mean & -15.56 & -9.08 & 6.48 & 303.15 & 70.48 & 85.50 & 15.02 & 391.75 \\
\hline & $\mathrm{SD}$ & 383.19 & 40.84 & 375.80 & 403.98 & 155.80 & 75.01 & 155.17 & 267.03 \\
\hline \multirow[t]{2}{*}{ DENMARK } & Mean & 39.80 & 29.01 & -10.78 & 358.51 & 177.12 & 219.63 & 42.51 & 498.39 \\
\hline & $\mathrm{SD}$ & 472.67 & 54.10 & 450.97 & 420.78 & 229.52 & 280.21 & 182.17 & 239.05 \\
\hline \multirow[t]{2}{*}{ FRANCE } & Mean & 21.16 & -6.61 & -27.78 & 339.87 & 60.64 & 87.56 & 26.92 & 381.91 \\
\hline & $\mathrm{SD}$ & 327.54 & 42.46 & 314.22 & 155.42 & 124.74 & 157.06 & 199.91 & 253.58 \\
\hline \multirow[t]{2}{*}{ GERMANY } & Mean & 3.97 & 22.60 & 18.64 & 322.68 & 54.34 & -125.23 & -179.57 & 375.61 \\
\hline & $\mathrm{SD}$ & 356.79 & 55.91 & 328.93 & 269.16 & 225.71 & 168.85 & 194.87 & 128.92 \\
\hline \multirow[t]{2}{*}{ ITALY } & Mean & 154.44 & 148.74 & -5.70 & 473.15 & -40.50 & 274.35 & 314.84 & 280.78 \\
\hline & $\mathrm{SD}$ & 470.49 & 98.46 & 473.03 & 411.58 & 255.11 & 265.03 & 367.79 & 412.17 \\
\hline \multirow[t]{2}{*}{ JAPAN } & Mean & 9.15 & 222.66 & 186.37 & 203.55 & -85.27 & -290.46 & -205.19 & 236.00 \\
\hline & $\mathrm{SD}$ & 607.85 & 75.83 & 621.49 & 553.46 & 268.16 & 179.97 & 335.58 & 312.58 \\
\hline \multirow[t]{2}{*}{ NETHERLANDS } & Mean & 55.43 & -16.86 & -72.29 & 374.14 & 35.58 & -77.80 & -113.38 & 356.85 \\
\hline & $\mathrm{SD}$ & 498.19 & 52.06 & 482.03 & 427.72 & 209.28 & 140.13 & 210.99 & 200.56 \\
\hline \multirow[t]{2}{*}{ NORWAY } & Mean & -6.45 & 19.47 & 25.91 & 312.26 & 48.23 & 70.33 & 22.10 & 369.50 \\
\hline & $\mathrm{SD}$ & 415.13 & 41.92 & 394.12 & 383.65 & 259.13 & 158.07 & 282.17 & 272.13 \\
\hline \multirow[t]{2}{*}{ PORTUGAL } & Mean & 178.24 & 215.06 & 36.81 & 496.96 & -303.32 & 331.06 & 634.38 & 17.95 \\
\hline & $\mathrm{SD}$ & 873.35 & 236.17 & 852.38 & 770.66 & 475.16 & 358.80 & 621.74 & 545.04 \\
\hline \multirow[t]{2}{*}{ SPAIN } & Mean & 259.98 & 445.19 & -60.04 & 454.39 & -81.95 & 254.96 & 336.91 & 239.32 \\
\hline & $\mathrm{SD}$ & 413.34 & 492.14 & 458.18 & 391.90 & 309.73 & 236.68 & 376.91 & 417.27 \\
\hline \multirow[t]{2}{*}{ SWEDEN } & Mean & 15.61 & 22.18 & 6.57 & 334.32 & 47.00 & 112.70 & 65.69 & 368.28 \\
\hline & SD & 504.39 & 44.58 & 488.70 & 442.96 & 217.23 & 151.47 & 247.79 & 264.17 \\
\hline \multirow[t]{2}{*}{ UK } & Mean & 0.35 & -60.54 & -60.90 & 319.07 & 15.22 & 159.07 & 143.85 & 336.49 \\
\hline & $\mathrm{SD}$ & 495.54 & 65.56 & 472.47 & 422.96 & 194.62 & 234.79 & 328.10 & 303.54 \\
\hline \multirow[t]{2}{*}{ US } & Mean & & & & 318.71 & & & & 321.27 \\
\hline & $\mathrm{SD}$ & & & & 343.85 & & & & 260.37 \\
\hline
\end{tabular}




\section{TABLE 3}

RIP convergence results (AR regression)

Panel A: 1872-1914

\begin{tabular}{lccccc}
\hline & $\alpha$ & $\mathrm{t}(\alpha=0)$ & $\beta$ & $\mathrm{t}(\beta=1)$ & $\mathrm{t}(\beta=0)$ \\
\cline { 2 - 6 } AUSTRALIA & 0.25 & 0.33 & 0.06 & $-6.05^{*}$ & 0.37 \\
BELGIUM & 0.26 & 0.32 & 0.16 & $-5.53^{*}$ & 1.02 \\
CANADA & -0.17 & -0.29 & -0.05 & $-6.91^{*}$ & -0.36 \\
DENMARK & 0.39 & 0.53 & 0.04 & $-6.29^{*}$ & 0.25 \\
FRANCE & 0.19 & 0.39 & 0.27 & $-5.08^{*}$ & 1.87 \\
GERMANY & 0.06 & 0.11 & 0.20 & $-5.49^{*}$ & 1.38 \\
ITALY & 1.37 & 1.81 & 0.12 & $-5.71^{*}$ & 0.81 \\
JAPAN & -0.02 & -0.01 & 0.22 & $-3.40^{*}$ & 0.93 \\
NETHERLANDS & 0.53 & 0.69 & 0.10 & $-6.20^{*}$ & 0.72 \\
NORWAY & -0.03 & -0.05 & 0.25 & $-5.01^{*}$ & 1.66 \\
PORTUGAL & 1.89 & 1.38 & -0.06 & $-6.81^{*}$ & -0.40 \\
SPAIN & 3.31 & $3.71^{*}$ & -0.40 & $-7.65^{*}$ & $-2.17 *$ \\
SWEDEN & 0.15 & 0.19 & 0.10 & $-5.84^{*}$ & 0.67 \\
UK & 0.01 & 0.01 & 0.07 & $-6.12^{*}$ & 0.48 \\
\hline
\end{tabular}

Panel B: 1974-2006

\begin{tabular}{lccccc}
\hline & $\alpha$ & $\mathrm{t}(\alpha=0)$ & $\beta$ & $\mathrm{t}(\beta=1)$ & $\mathrm{t}(\beta=0)$ \\
\cline { 2 - 6 } AUSTRALIA & 0.19 & 0.69 & 0.66 & $-2.69^{*}$ & $5.12^{*}$ \\
BELGIUM & 0.22 & 0.76 & 0.70 & $-2.36^{*}$ & $5.42^{*}$ \\
CANADA & 0.54 & $2.01^{*}$ & 0.35 & $-4.11^{*}$ & $2.25^{*}$ \\
DENMARK & 0.48 & 1.30 & 0.71 & $-2.25^{*}$ & $5.58^{*}$ \\
FRANCE & 0.36 & 1.60 & 0.43 & $-3.51^{*}$ & $2.69^{*}$ \\
GERMANY & 0.15 & 0.48 & 0.64 & $-2.61^{*}$ & $4.72^{*}$ \\
ITALY & 0.03 & 0.14 & 0.80 & -1.97 & $8.08^{*}$ \\
JAPAN & -0.27 & -0.65 & 0.55 & $-3.09^{*}$ & $3.77^{*}$ \\
NETHERLANDS & 0.19 & 0.60 & 0.59 & $-2.85^{*}$ & $4.04^{*}$ \\
NORWAY & 0.48 & 1.14 & 0.29 & $-4.39^{*}$ & 1.79 \\
PORTUGAL & -0.72 & -1.02 & 0.70 & $-2.37^{*}$ & $5.62^{*}$ \\
SPAIN & -0.21 & -0.52 & 0.69 & $-2.42^{*}$ & $5.31^{*}$ \\
SWEDEN & 0.27 & 0.76 & 0.46 & $-3.41^{*}$ & $2.85^{*}$ \\
UK & 0.10 & 0.30 & 0.15 & $-4.78^{*}$ & 0.87 \\
\hline
\end{tabular}

$Y_{t}=\alpha_{1}+\beta_{1} Y_{t-1}+\varepsilon_{t}$

* denotes statistical significance at the $5 \%$ level. 


\section{TABLE 4}

Nominal Interest Rate Differential convergence results (AR regression)

Panel A: 1872-1914

\begin{tabular}{lccccc}
\hline & $\alpha$ & $\mathrm{t}(\alpha=0)$ & $\beta$ & $\mathrm{t}(\beta=1)$ & $\mathrm{t}(\beta=0)$ \\
\cline { 2 - 6 } AUSTRALIA & 0.10 & 1.59 & 0.75 & $-2.45^{*}$ & $7.52^{*}$ \\
BELGIUM & 0.02 & 0.49 & 0.89 & -1.27 & $9.88^{*}$ \\
CANADA & -0.01 & -0.23 & 0.78 & $-2.24^{*}$ & $7.80^{*}$ \\
DENMARK & 0.06 & 1.48 & 0.88 & -1.69 & $12.13^{*}$ \\
FRANCE & -0.01 & -0.31 & 0.77 & $-2.24^{*}$ & $7.71^{*}$ \\
GERMANY & 0.06 & 1.44 & 0.86 & $-2.04^{*}$ & $12.89^{*}$ \\
ITALY & 0.12 & 0.95 & 0.89 & -1.47 & $12.40^{*}$ \\
JAPAN & 0.40 & 1.93 & 0.81 & $-2.10^{*}$ & $9.20^{*}$ \\
NETHERLANDS & -0.01 & -0.27 & 0.83 & $-2.02^{*}$ & $10.11^{*}$ \\
NORWAY & 0.06 & 1.30 & 0.74 & $-2.58^{*}$ & $7.22^{*}$ \\
PORTUGAL & 0.53 & 1.60 & 0.75 & $-2.43^{*}$ & $7.25^{*}$ \\
SPAIN & 0.47 & 0.96 & 0.88 & -1.56 & $11.84^{*}$ \\
SWEDEN & 0.06 & 1.32 & 0.77 & $-2.37^{*}$ & $8.10^{*}$ \\
UK & -0.02 & -0.44 & 0.90 & -1.77 & $15.31^{*}$ \\
\hline
\end{tabular}

Panel B: 1974-2006

\begin{tabular}{lccccl}
\hline & $\alpha$ & $\mathrm{t}(\alpha=0)$ & $\beta$ & $\mathrm{t}(\beta=1)$ & $\mathrm{t}(\beta=0)$ \\
\cline { 2 - 6 } AUSTRALIA & 0.48 & 1.74 & 0.73 & $-2.25^{*}$ & $6.12^{*}$ \\
BELGIUM & -0.01 & -0.10 & 0.72 & $-2.16^{*}$ & $5.43^{*}$ \\
CANADA & 0.19 & 1.24 & 0.74 & -1.89 & $5.45^{*}$ \\
DENMARK & 0.05 & 0.16 & 0.91 & -1.12 & $11.38^{*}$ \\
FRANCE & -0.01 & -0.04 & 0.90 & -1.17 & $10.83^{*}$ \\
GERMANY & -0.41 & $-2.08^{*}$ & 0.76 & $-2.55^{*}$ & $8.22^{*}$ \\
ITALY & 0.37 & 0.99 & 0.86 & -1.44 & $8.94^{*}$ \\
JAPAN & -0.69 & $-2.17^{*}$ & 0.80 & $-2.18^{*}$ & $8.54^{*}$ \\
NETHERLANDS & -0.23 & -1.39 & 0.79 & $-2.07^{*}$ & $7.62^{*}$ \\
NORWAY & 0.17 & 0.85 & 0.77 & $-2.01^{*}$ & $6.62^{*}$ \\
PORTUGAL & 0.40 & 1.00 & 0.89 & -1.39 & $11.01^{*}$ \\
SPAIN & 0.24 & 0.66 & 0.87 & -1.27 & $8.56^{*}$ \\
SWEDEN & 0.16 & 0.76 & 0.82 & -1.57 & $7.30^{*}$ \\
UK & 0.07 & 0.29 & 0.88 & -1.44 & $10.27^{*}$ \\
\hline
\end{tabular}

$Y_{t}=\alpha_{1}+\beta_{1} Y_{t-1}+\varepsilon_{t}$

* denotes statistical significance at the 5\% level. 
TABLE 5

Inflation Differential convergence results (AR regression)

Panel A: 1872-1914

\begin{tabular}{lccccc}
\hline & $\alpha$ & $\mathrm{t}(\alpha=0)$ & $\beta$ & $\mathrm{t}(\beta=1)$ & $\mathrm{t}(\beta=0)$ \\
\cline { 2 - 6 } AUSTRALIA & 0.05 & 0.06 & 0.00 & $-6.39^{*}$ & 0.00 \\
BELGIUM & -0.43 & -0.55 & 0.09 & $-5.90^{*}$ & 0.59 \\
CANADA & 0.08 & 0.14 & -0.10 & $-7.19^{*}$ & -0.64 \\
DENMARK & -0.11 & -0.16 & -0.05 & $-6.85^{*}$ & -0.33 \\
FRANCE & -0.24 & -0.52 & 0.22 & $-5.40^{*}$ & 1.51 \\
GERMANY & 0.17 & 0.33 & 0.07 & $-6.23^{*}$ & 0.45 \\
ITALY & -0.07 & -0.10 & 0.17 & $-5.47^{*}$ & 1.12 \\
JAPAN & 1.31 & 0.94 & 0.30 & $-3.09^{*}$ & 1.36 \\
NETHERLANDS & -0.70 & -0.94 & 0.06 & $-6.47^{*}$ & 0.41 \\
NORWAY & 0.20 & 0.34 & 0.18 & $-5.38^{*}$ & 1.17 \\
PORTUGAL & 0.41 & 0.32 & -0.11 & $-7.17^{*}$ & -0.73 \\
SPAIN & -0.42 & -0.45 & -0.19 & $-5.83^{*}$ & -0.92 \\
SWEDEN & 0.06 & 0.08 & 0.05 & $-6.14^{*}$ & 0.34 \\
UK & -0.62 & -0.85 & -0.03 & $-6.66^{*}$ & -0.17 \\
\hline
\end{tabular}

Panel B: 1974-2006

\begin{tabular}{lcrccc}
\hline & $\alpha$ & $\mathrm{t}(\alpha=0)$ & $\beta$ & $\mathrm{t}(\beta=1)$ & $\mathrm{t}(\beta=0)$ \\
\cline { 2 - 5 } AUSTRALIA & 0.47 & 1.08 & 0.62 & $-2.69^{*}$ & $4.44^{*}$ \\
BELGIUM & -0.23 & -0.79 & 0.70 & $-2.37^{*}$ & $5.41^{*}$ \\
CANADA & -0.01 & -0.04 & 0.40 & $-3.83^{*}$ & $2.53^{*}$ \\
DENMARK & 0.04 & 0.17 & 0.66 & $-2.58^{*}$ & $4.95^{*}$ \\
FRANCE & -0.01 & -0.05 & 0.71 & $-2.31^{*}$ & $5.56^{*}$ \\
GERMANY & -0.75 & $-2.10^{*}$ & 0.62 & $-2.81^{*}$ & $4.60^{*}$ \\
ITALY & 0.30 & 0.63 & 0.86 & -1.40 & $8.78^{*}$ \\
JAPAN & -0.86 & -1.90 & 0.69 & $-2.67^{*}$ & $5.97^{*}$ \\
NETHERLANDS & -0.50 & -1.61 & 0.65 & $-2.68^{*}$ & $4.96^{*}$ \\
NORWAY & 0.01 & 0.02 & 0.42 & $-3.64^{*}$ & $2.67^{*}$ \\
PORTUGAL & 0.89 & 0.95 & 0.84 & -1.58 & $8.00^{*}$ \\
SPAIN & 0.51 & 0.94 & 0.81 & -1.76 & $7.53^{*}$ \\
SWEDEN & 0.22 & 0.59 & 0.60 & $-2.70^{*}$ & $4.10^{*}$ \\
UK & 0.29 & 0.65 & 0.73 & $-2.15^{*}$ & $5.96^{*}$ \\
\hline
\end{tabular}

$Y_{t}=\alpha_{1}+\beta_{1} Y_{t-1}+\varepsilon_{t}$

* denotes statistical significance at the 5\% level. 
TABLE 6

Real Interest Rate Reversion in Each Country (AR regression)

Panel A: 1872-1914

AUSTRALIA

BELGIUM

CANADA

DENMARK

FRANCE

GERMANY

ITALY

JAPAN

NETHERLANDS

NORWAY

PORTUGAL

SPAIN

SWEDEN

UK

US

\begin{tabular}{ccccc}
$\alpha$ & $\mathrm{t}(\alpha=0)$ & $\beta$ & $\mathrm{t}(\beta=1)$ & $\mathrm{t}(\beta=0)$ \\
\hline 3.08 & $3.50^{*}$ & 0.11 & $-5.74^{*}$ & 0.68 \\
3.04 & $3.34^{*}$ & 0.12 & $-5.65^{*}$ & 0.80 \\
2.53 & $3.27^{*}$ & 0.16 & $-5.42^{*}$ & 1.06 \\
2.94 & $3.50^{*}$ & 0.18 & $-5.35^{*}$ & 1.17 \\
3.30 & $5.76^{*}$ & 0.03 & $-6.30^{*}$ & 0.19 \\
2.17 & $3.58^{*}$ & 0.33 & $-4.61^{*}$ & $2.28^{*}$ \\
4.23 & $4.36^{*}$ & 0.11 & $-5.76^{*}$ & 0.68 \\
1.47 & 1.22 & 0.20 & $-3.38^{*}$ & 0.85 \\
3.08 & $3.71^{*}$ & 0.19 & $-5.56^{*}$ & 1.28 \\
1.79 & $2.55^{*}$ & 0.42 & $-4.08^{*}$ & $2.97^{*}$ \\
5.53 & $3.91^{*}$ & -0.11 & $-7.20^{*}$ & -0.72 \\
5.21 & $4.72^{*}$ & -0.23 & $-6.66^{*}$ & -1.26 \\
2.64 & $3.13^{*}$ & 0.21 & $-5.17^{*}$ & 1.38 \\
3.45 & $4.18^{*}$ & -0.08 & $-6.87^{*}$ & -0.51 \\
1.49 & $2.39^{*}$ & 0.51 & $-3.71^{*}$ & $3.92^{*}$
\end{tabular}

Panel B: 1974-2006

\begin{tabular}{lccccc}
\hline & $\alpha$ & $\mathrm{t}(\alpha=0)$ & $\beta$ & $\mathrm{t}(\beta=1)$ & $\mathrm{t}(\beta=0)$ \\
\cline { 2 - 6 } AUSTRALIA & 0.74 & 1.66 & 0.83 & -1.95 & $9.24^{*}$ \\
BELGIUM & 0.62 & 1.51 & 0.85 & -1.67 & $9.74^{*}$ \\
CANADA & 1.13 & $2.28^{*}$ & 0.74 & $-2.47^{*}$ & $7.19^{*}$ \\
DENMARK & 1.00 & 1.64 & 0.80 & -1.83 & $7.30^{*}$ \\
FRANCE & 0.85 & 1.74 & 0.79 & $-1.99^{*}$ & $7.47^{*}$ \\
GERMANY & 1.36 & $2.39^{*}$ & 0.64 & $-2.55^{*}$ & $4.53^{*}$ \\
ITALY & 0.60 & 1.37 & 0.84 & -1.82 & $9.64^{*}$ \\
JAPAN & 0.95 & $2.00^{*}$ & 0.67 & $-2.75^{*}$ & $5.53^{*}$ \\
NETHERLANDS & 0.71 & 1.95 & 0.82 & $-2.00^{*}$ & $9.35^{*}$ \\
NORWAY & 1.89 & $3.21^{*}$ & 0.54 & $-3.61^{*}$ & $4.25^{*}$ \\
PORTUGAL & 0.26 & 0.46 & 0.79 & $-2.05^{*}$ & $7.62^{*}$ \\
SPAIN & 0.33 & 0.89 & 0.89 & -1.41 & $11.77^{*}$ \\
SWEDEN & 1.27 & $2.15^{*}$ & 0.67 & $-2.54^{*}$ & $5.17^{*}$ \\
UK & 1.34 & $2.07^{*}$ & 0.61 & $-2.75^{*}$ & $4.28^{*}$ \\
US & 0.65 & 1.52 & 0.81 & -1.86 & $7.84^{*}$ \\
\hline
\end{tabular}

$Y_{t}=\alpha_{1}+\beta_{1} Y_{t-1}+\varepsilon_{t}$

* denotes statistical significance at the 5\% level. 
TABLE 7

Comovement Descriptive Statistics

\begin{tabular}{|c|c|c|c|c|c|}
\hline & & Mean & SD & $\begin{array}{c}\text { Mean } \\
1872-1914\end{array}$ & $\begin{array}{c}\text { Mean } \\
\text { 1974-2006 }\end{array}$ \\
\hline \multirow[t]{2}{*}{ AUSTRALIA } & RIP_NID & 0.06 & 0.77 & 0.17 & -0.08 \\
\hline & RIP_INFDIF & -0.93 & 1.48 & -1.42 & -0.29 \\
\hline \multirow[t]{2}{*}{ BELGIUM } & RIP_NID & 0.27 & 1.00 & 0.40 & 0.10 \\
\hline & RIP_INFDIF & -0.97 & 1.89 & -1.51 & -0.25 \\
\hline \multirow[t]{2}{*}{ CANADA } & RIP_NID & 0.25 & 0.85 & 0.24 & 0.26 \\
\hline & RIP_INFDIF & -0.96 & 1.89 & -1.52 & -0.21 \\
\hline \multirow[t]{2}{*}{ DENMARK } & RIP_NID & 0.42 & 1.02 & 0.21 & 0.70 \\
\hline & RIP_INFDIF & -0.84 & 2.26 & -1.46 & -0.01 \\
\hline \multirow[t]{2}{*}{ FRANCE } & RIP_NID & 0.12 & 0.84 & 0.16 & 0.06 \\
\hline & RIP_INFDIF & -0.90 & 1.67 & -1.43 & -0.19 \\
\hline \multirow[t]{2}{*}{ GERMANY } & RIP_NID & 0.30 & 0.99 & 0.24 & 0.37 \\
\hline & RIP_INFDIF & -0.89 & 1.72 & -1.29 & -0.37 \\
\hline \multirow[t]{2}{*}{ ITALY } & RIP_NID & -0.07 & 0.75 & -0.02 & -0.13 \\
\hline & RIP_INFDIF & -0.89 & 1.80 & -1.22 & -0.45 \\
\hline \multirow[t]{2}{*}{ JAPAN } & RIP_NID & 0.09 & 1.08 & -0.02 & 0.30 \\
\hline & RIP_INFDIF & -1.76 & 3.80 & -2.76 & 0.09 \\
\hline \multirow[t]{2}{*}{ NETHERLANDS } & RIP_NID & 0.23 & 0.70 & 0.24 & 0.22 \\
\hline & RIP_INFDIF & -0.96 & 1.96 & -1.53 & -0.20 \\
\hline \multirow[t]{2}{*}{ NORWAY } & RIP_NID & 0.21 & 0.60 & 0.26 & 0.14 \\
\hline & RIP_INFDIF & -0.94 & 2.00 & -1.29 & -0.46 \\
\hline \multirow[t]{2}{*}{ PORTUGAL } & RIP_NID & 0.00 & 0.88 & 0.15 & -0.19 \\
\hline & RIP_INFDIF & -0.92 & 1.89 & -1.20 & -0.54 \\
\hline \multirow[t]{2}{*}{ SPAIN } & RIP_NID & -0.05 & 0.73 & -0.39 & 0.58 \\
\hline & RIP_INFDIF & -1.78 & 2.64 & -2.71 & -0.07 \\
\hline \multirow[t]{2}{*}{ SWEDEN } & RIP_NID & 0.17 & 0.65 & 0.21 & 0.12 \\
\hline & RIP_INFDIF & -0.95 & 2.29 & -1.46 & -0.26 \\
\hline \multirow[t]{2}{*}{ UK } & RIP_NID & 0.09 & 1.05 & 0.22 & -0.07 \\
\hline & RIP_INFDIF & -0.88 & 1.68 & -1.36 & -0.25 \\
\hline
\end{tabular}


FIGURE 1: Plots of nominal interest parity and inflation differentials

\section{Gold standard}

Australia

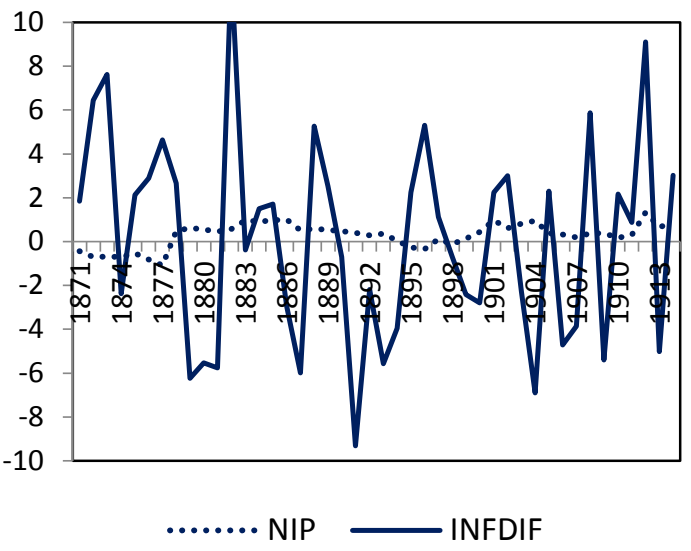

Belgium

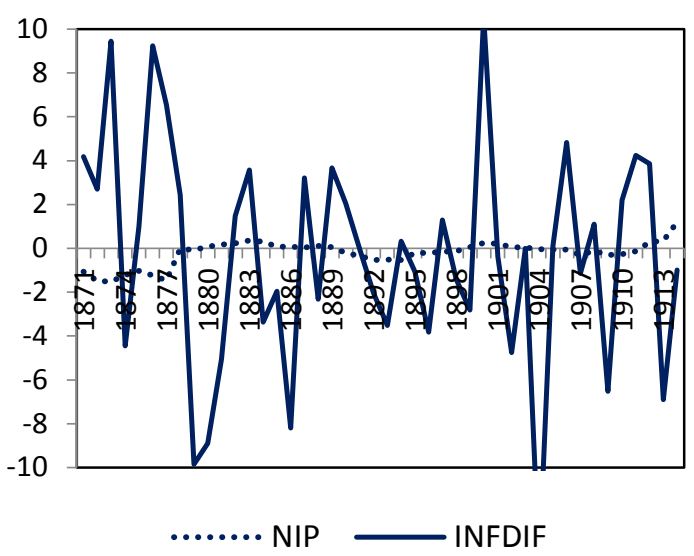

Canada

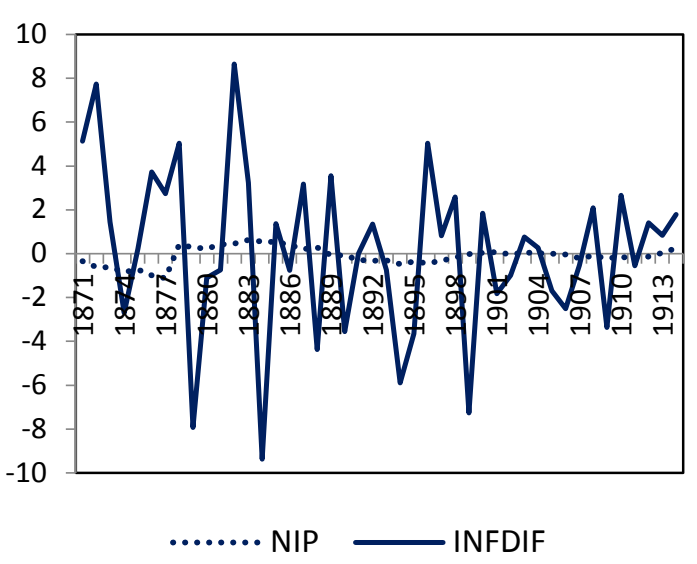

Float

\section{Australia}

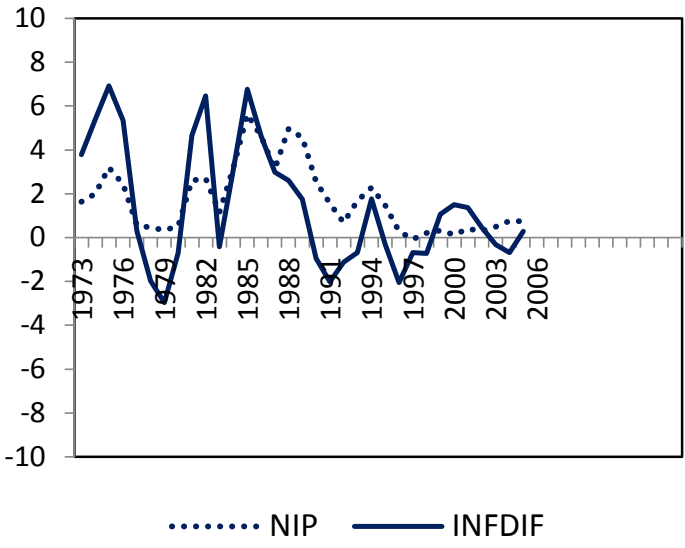

Belgium

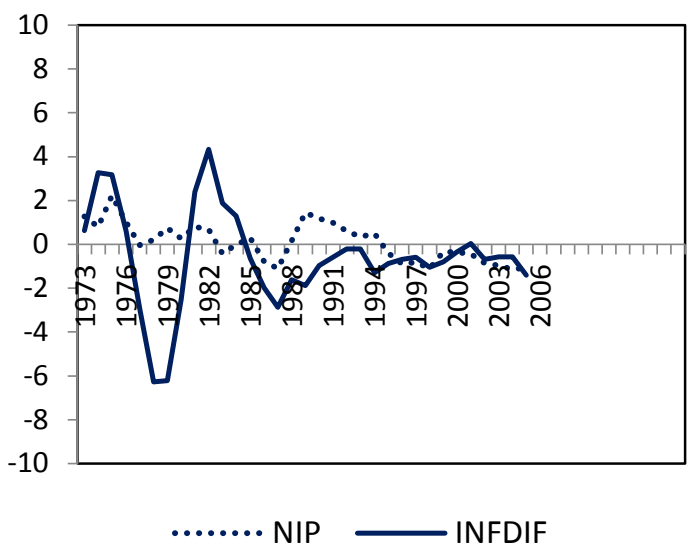

Canada

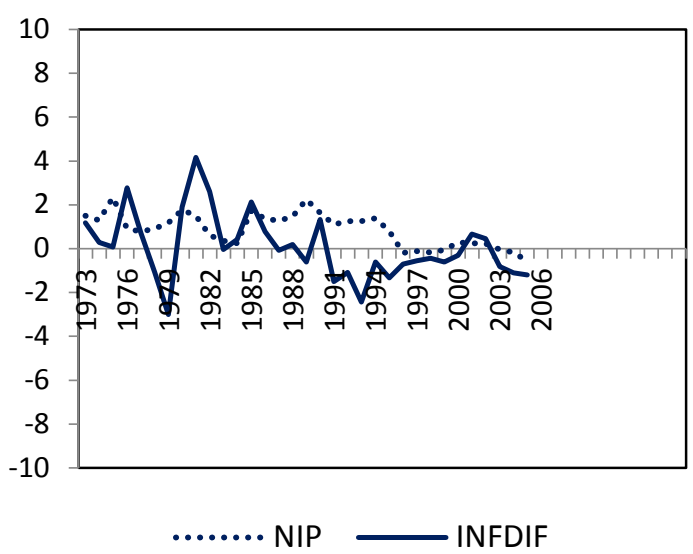


Gold standard

Denmark

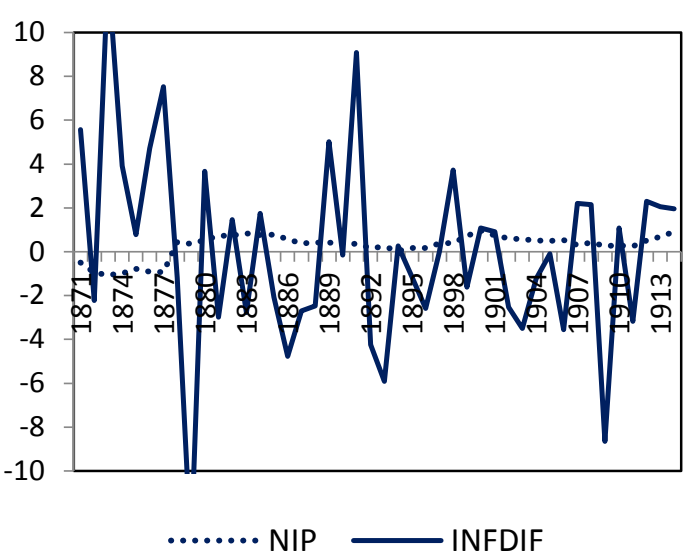

France

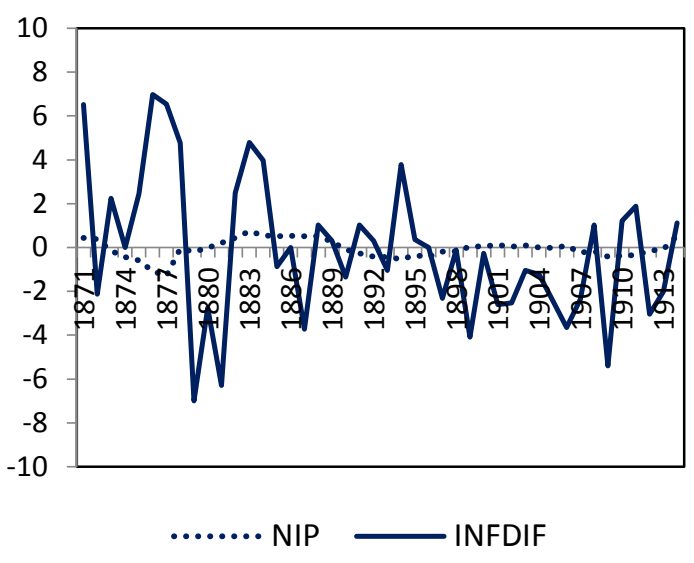

Germany

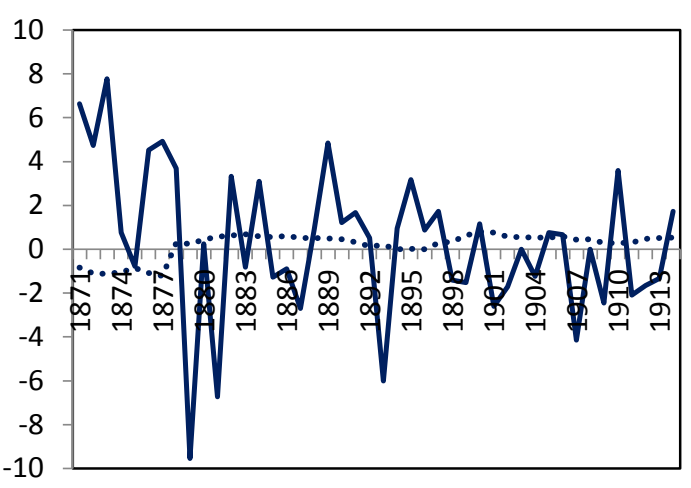

NIP INFDIF
Float

Denmark

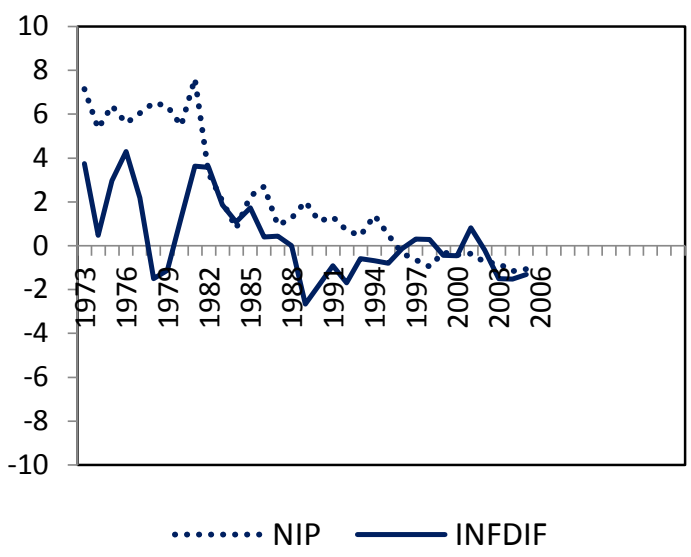

France

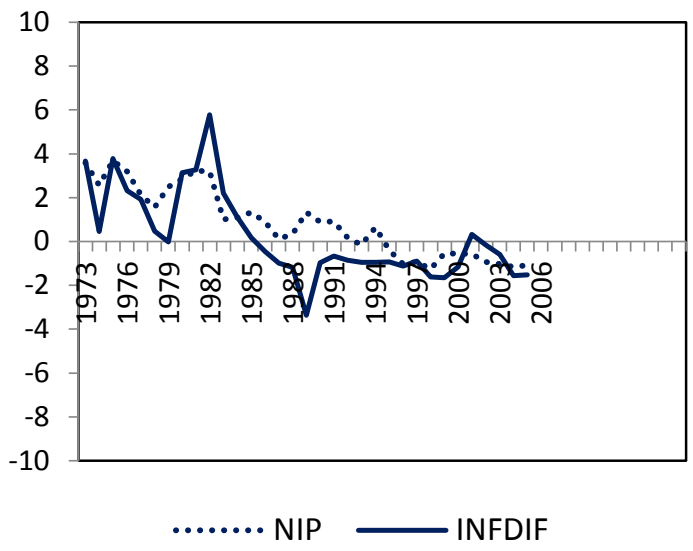

Germany

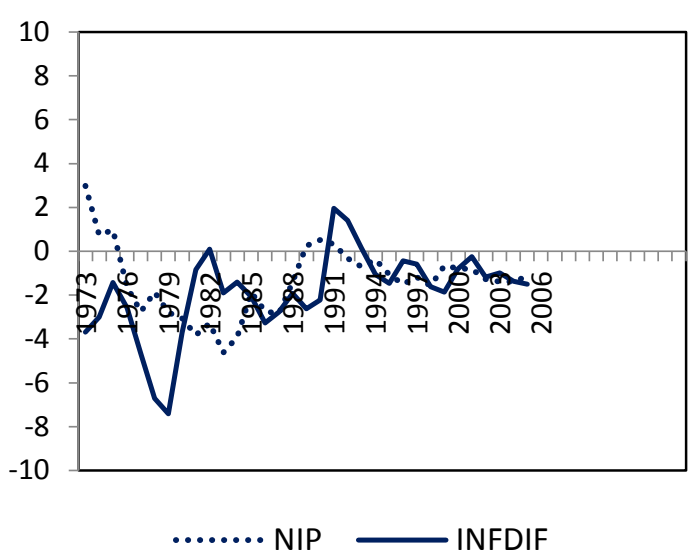


Gold standard

Italy

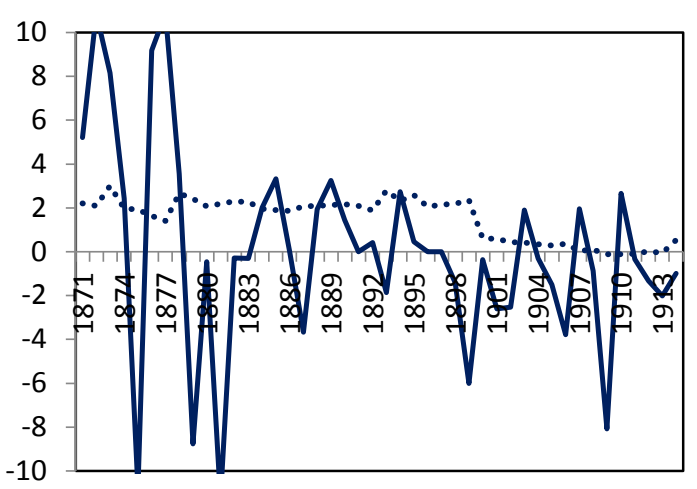

NIP INFDIF

Japan

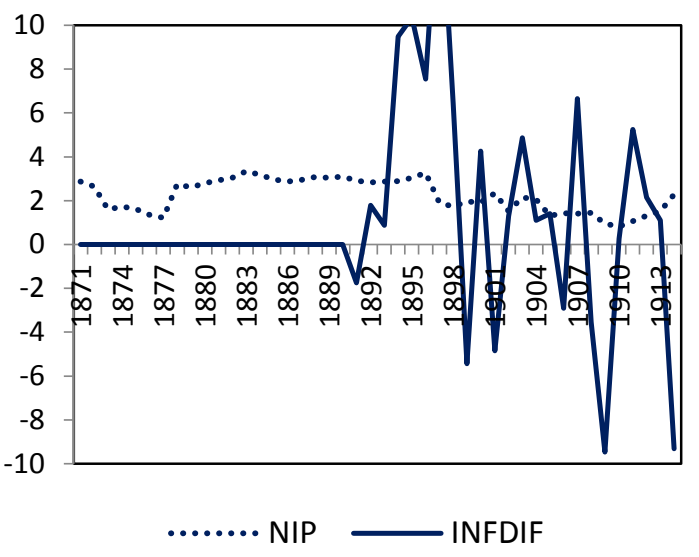

Netherlands

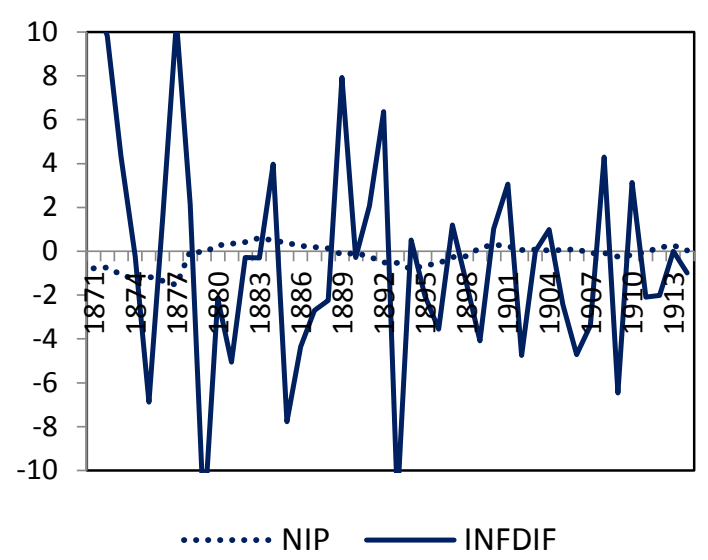

Float

Italy

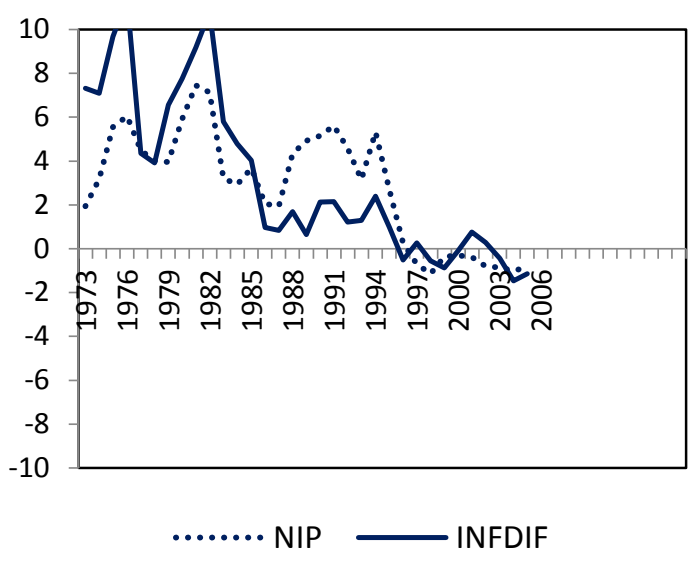

Japan

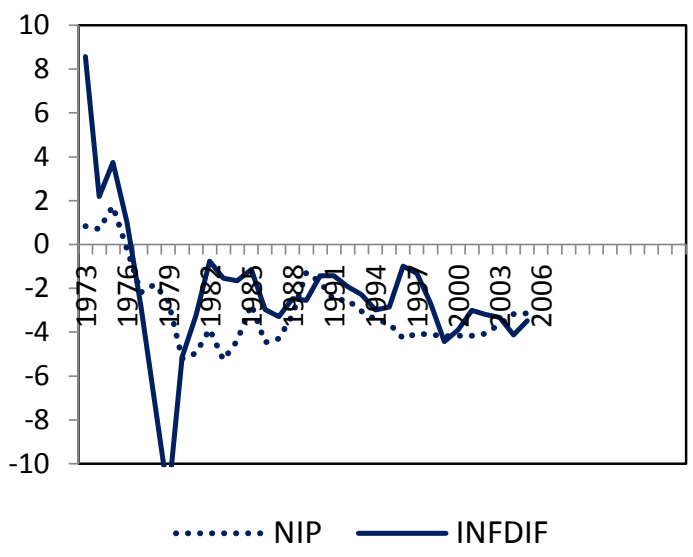

Netherlands

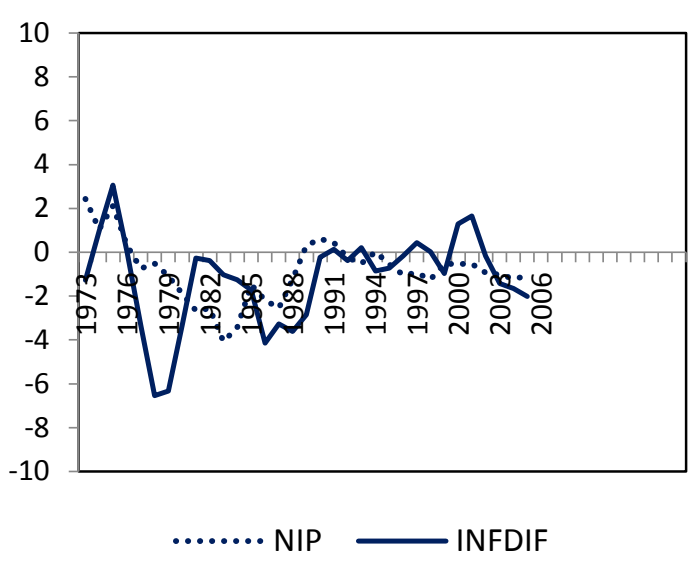


Gold standard

Norway

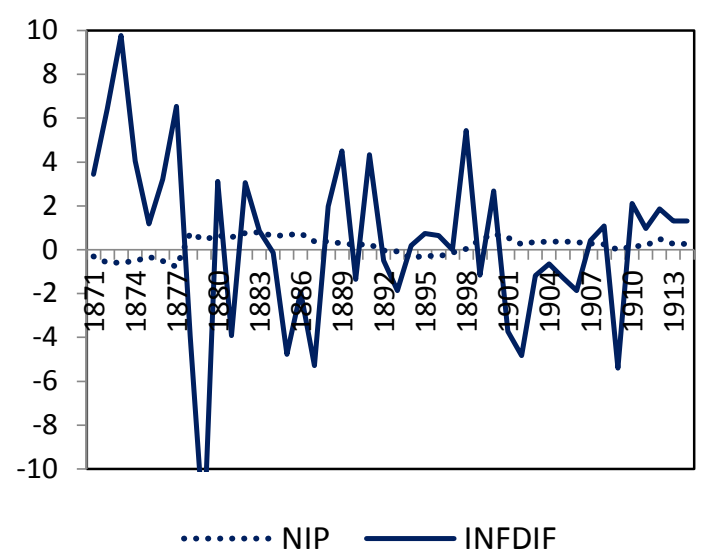

Portugal

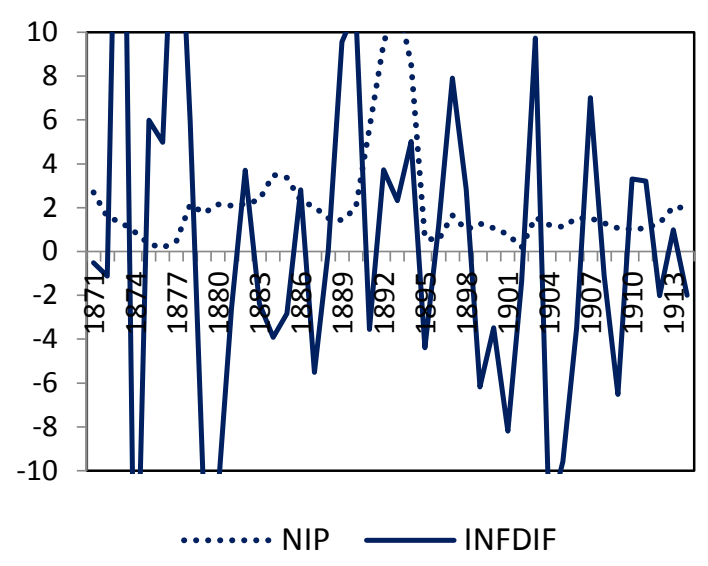

Spain

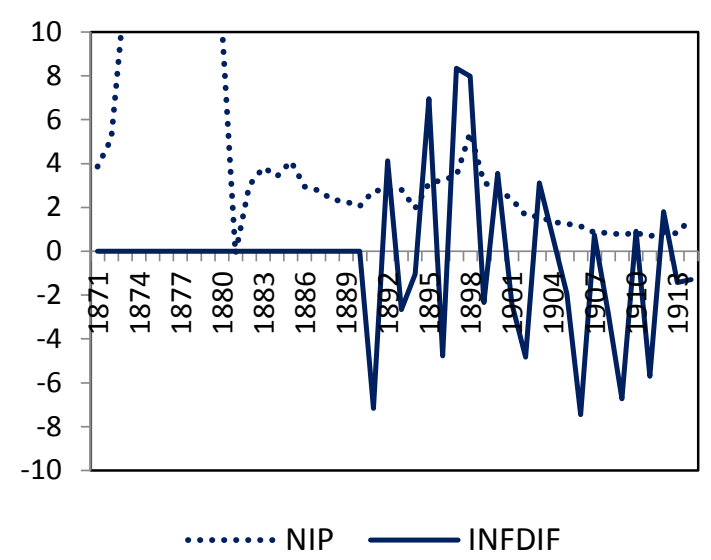

Float

Norway

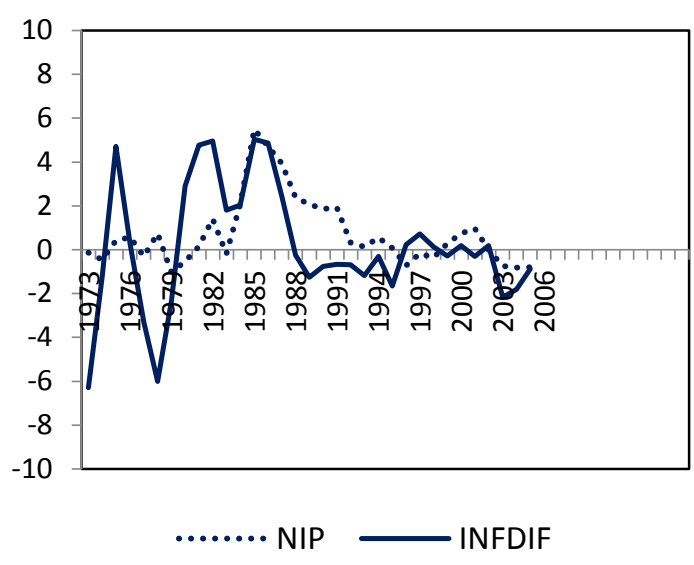

Portugal

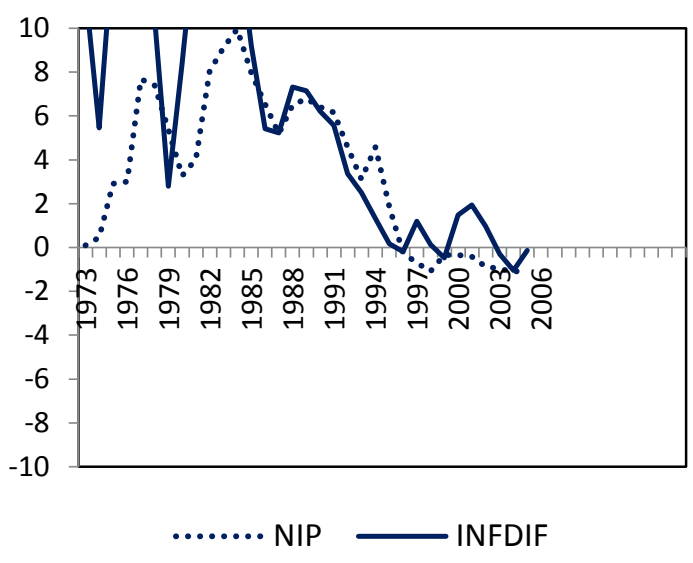

Spain

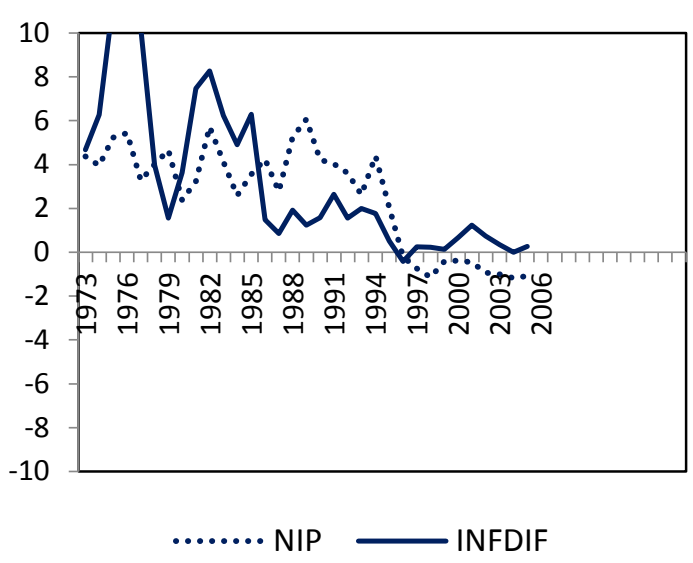


Gold standard

Sweden

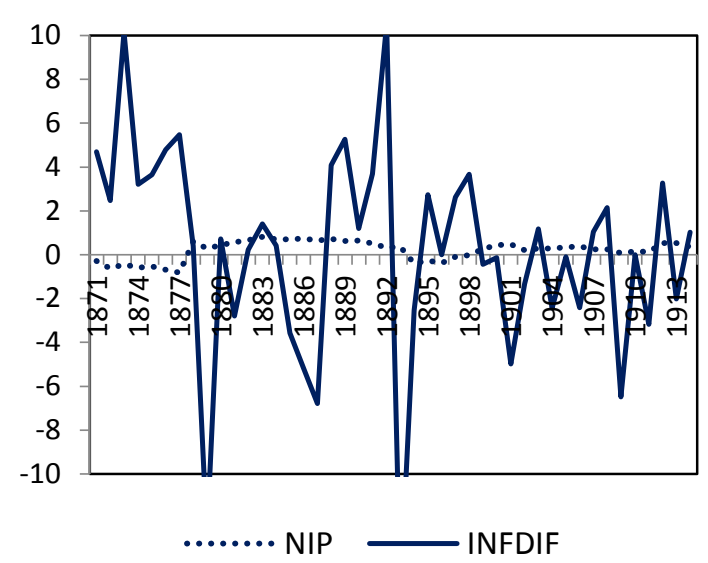

UK

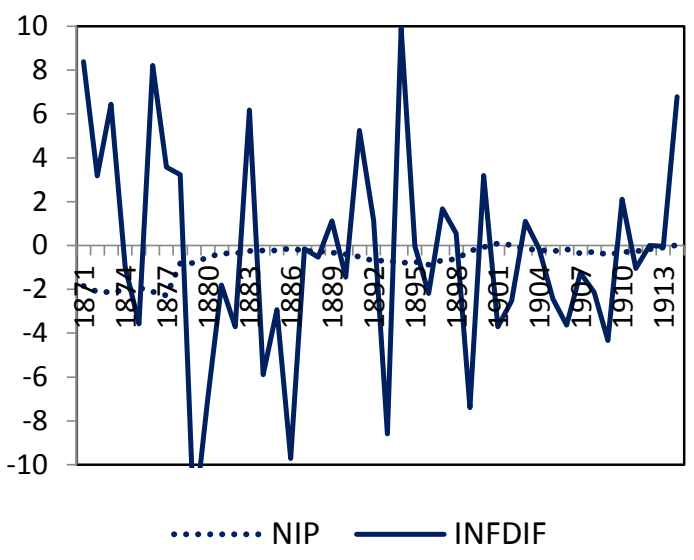

Float

Sweden

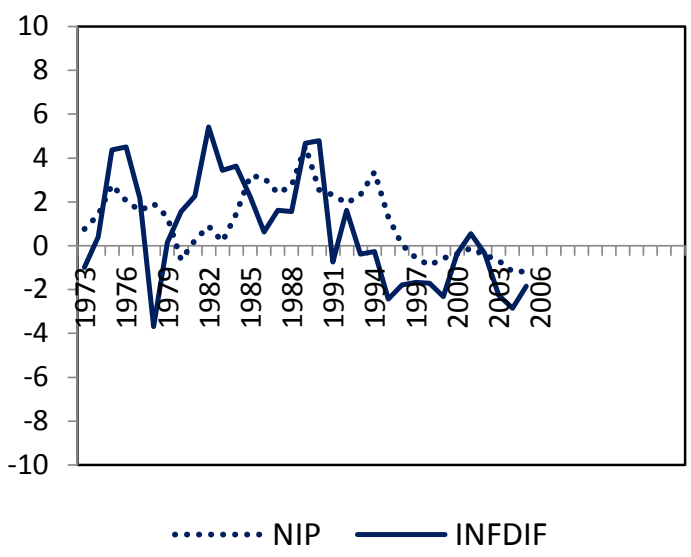

UK

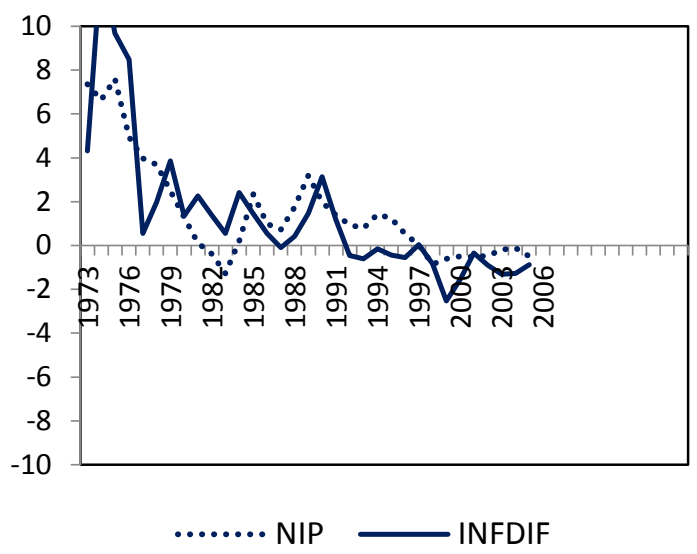


FIGURE 2: Comovements, $\rho_{t}^{x y}$, over the Gold Standard and Floating Periods

Australia

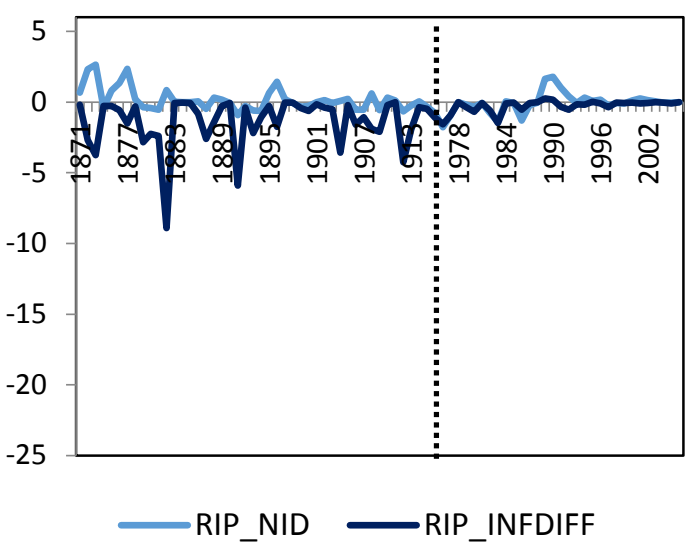

Canada

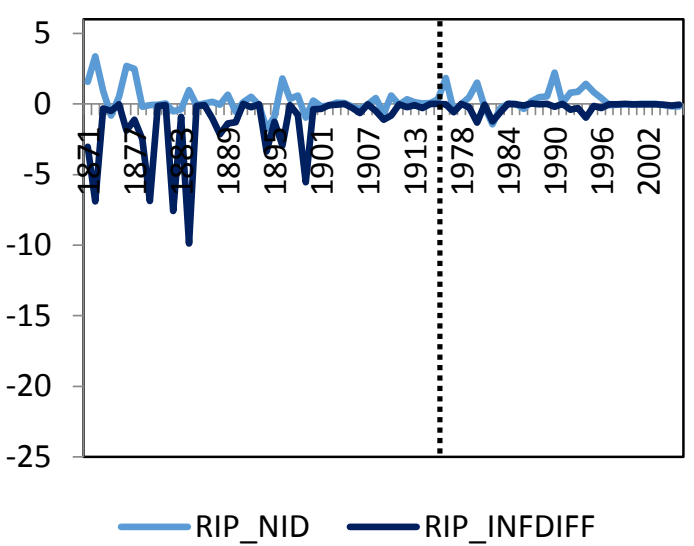

France

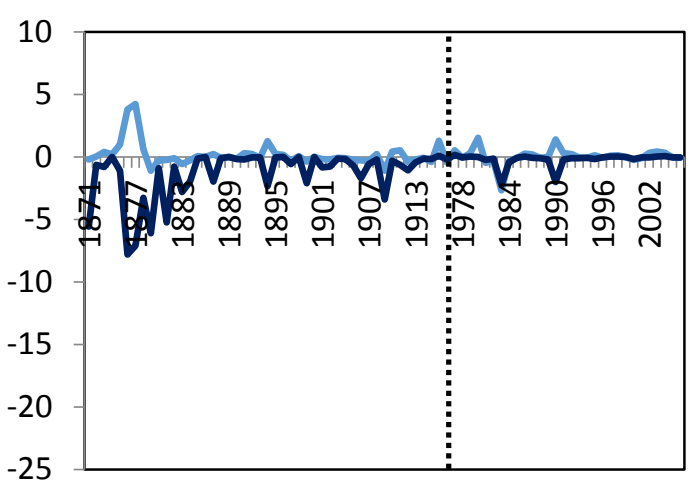

-RIP_NID -RIP_INFDIFF
Belgium

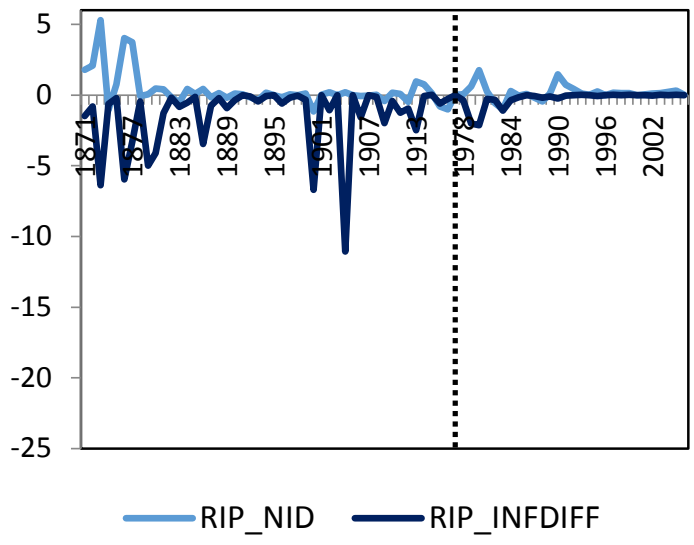

Denmark

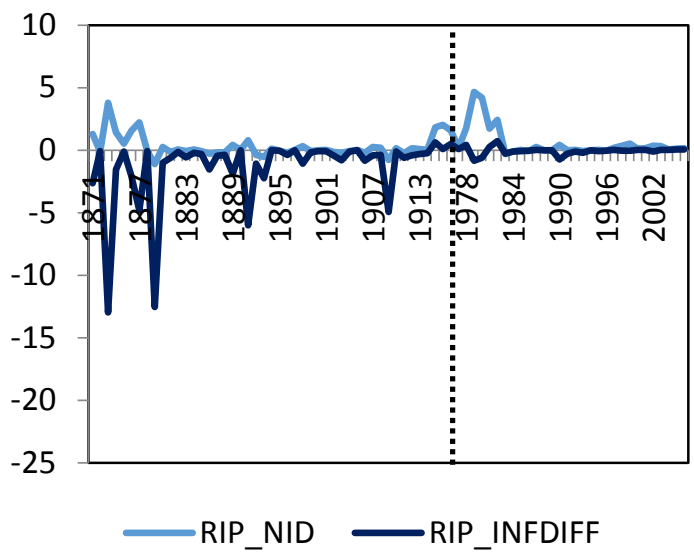

Germany

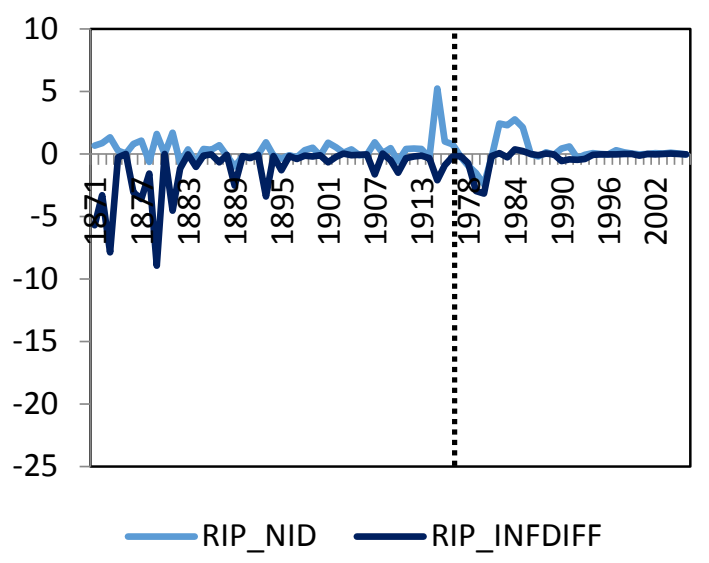


Italy

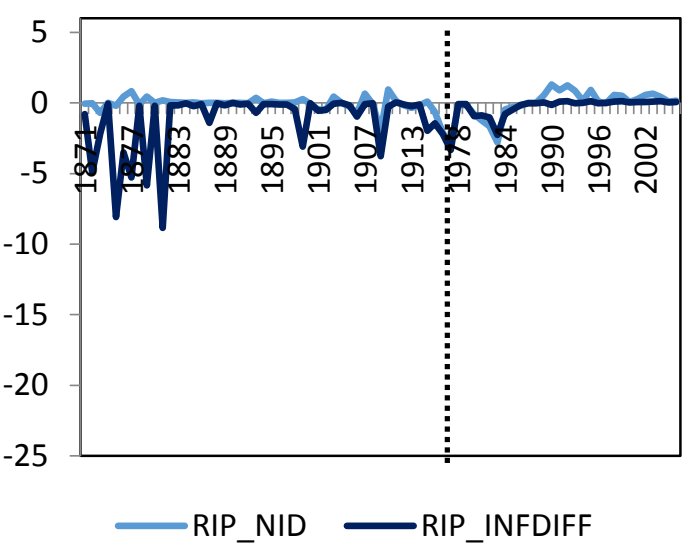

Netherlands

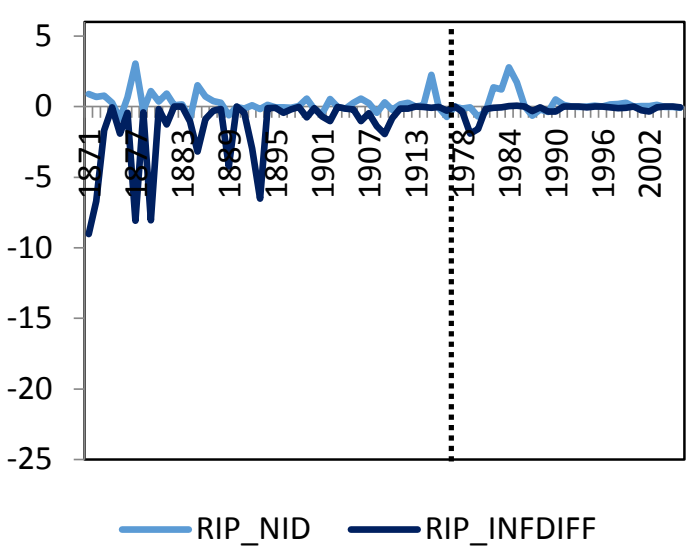

Portugal

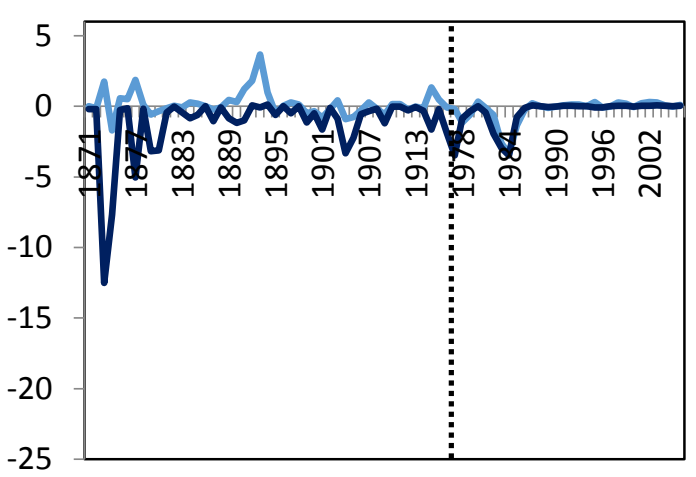

RIP_NID RIP_INFDIFF
Japan

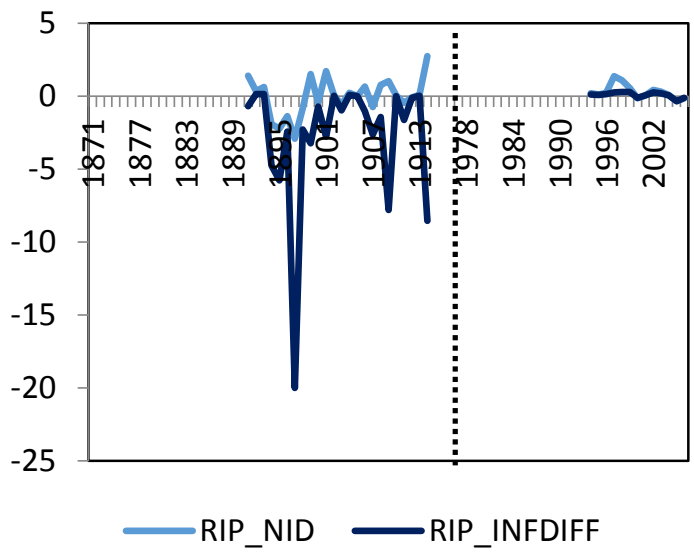

Norway

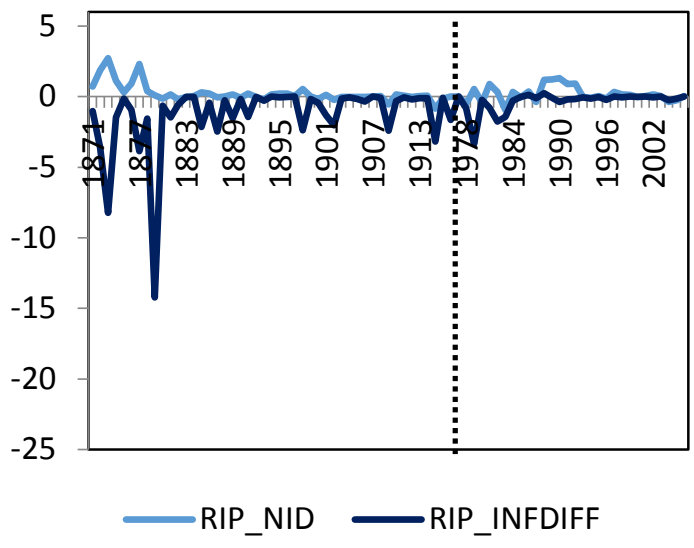

Spain

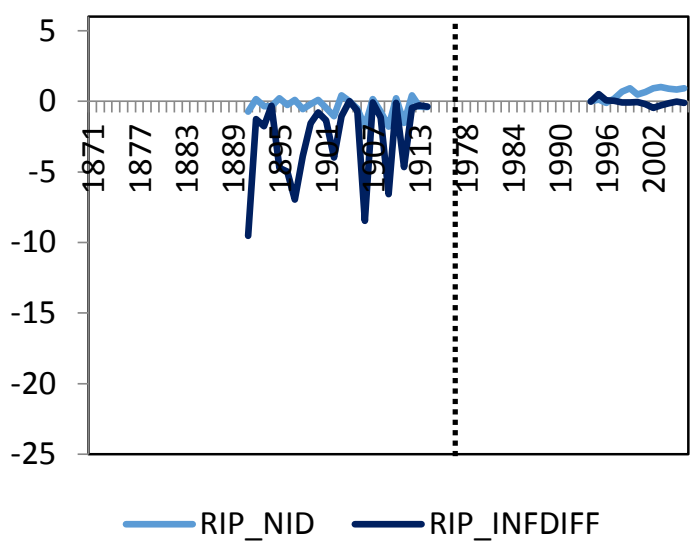


Sweden

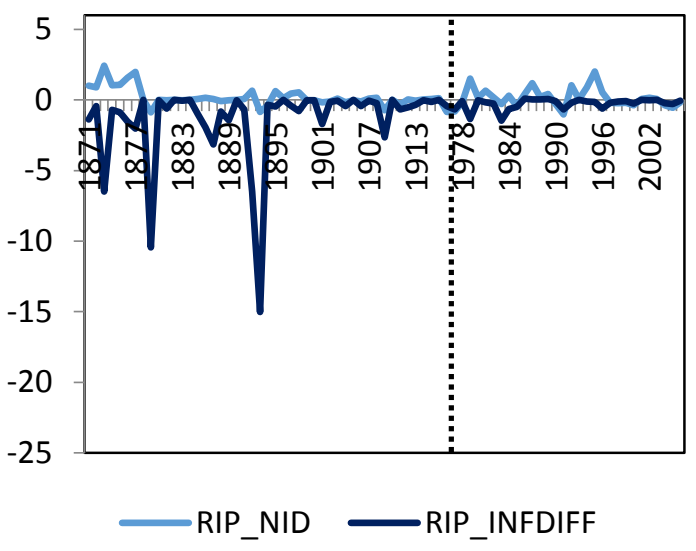

UK

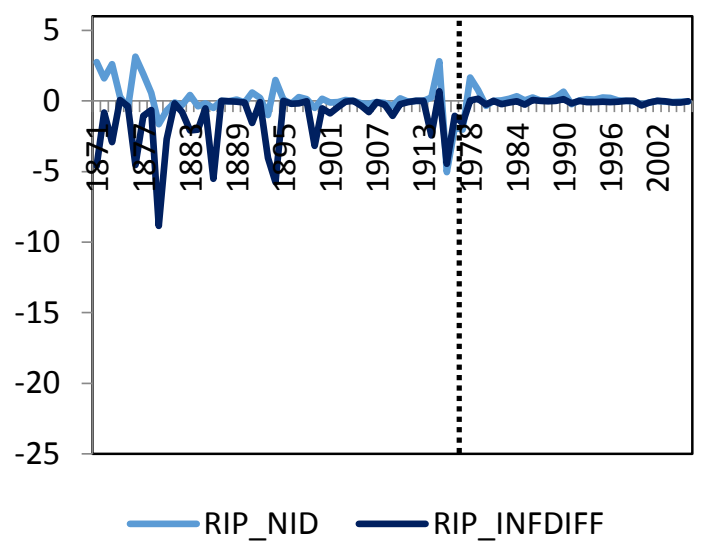




\section{APPENDIX - REAL INTEREST PARITY}

Real interest rate parity (RIP) in its strictest form simply states that the expected domestic real interest rate is equal to the expected foreign real interest rate:

$E_{t} r_{t, t+1}=E_{t} r_{t, t+1}^{*}$

where $\mathrm{E}$ is expectations, $\mathrm{t}$ denotes the time period, $\mathrm{r}$ is the real interest rate and an asterisk denotes the foreign country.

The relationship can be theoretically defined if three conditions hold. First the Fisher equation must hold in both the domestic market and the foreign market. The Fisher equation states that the expected real interest rate equals the nominal interest rate minus expected inflation:

$$
\begin{aligned}
& E_{t} r_{t, t+1}=i_{t, t+1}-E_{t} \pi_{t, t+1} \\
& E_{t} r_{t, t+1}^{*}=i_{t, t+1}^{*}-E_{t} \pi_{t, t+1}^{*}
\end{aligned}
$$

Secondly, uncovered interest rate parity (UIP) must hold. UIP states that expected changes in the exchange rate are equal to the difference in nominal interest rates between the domestic and international market:

$$
E_{t}\left(s_{t+1}-s_{t}\right)=i_{t, t+1}-i_{t, t+1}^{*}
$$

Thirdly, relative purchasing power parity (RPPP) must hold. RPPP states that expected changes in the exchange rate are equal to the difference in inflation between the domestic and international market:

$$
E_{t}\left(s_{t+1}-s_{t}\right)=E_{t} \pi_{t, t+1}-E_{t} \pi_{t, t+1}^{*}
$$

Using these three conditions we start from the fisher equation in the domestic market. We then assume UIP and PPP holds so we can state that the real interest rate in the domestic 
country equals the difference between the foreign nominal interest rate and the foreign expected inflation. By assuming the fisher effect holds in the foreign country we can replace the difference between the foreign nominal interest rate and the foreign expected inflation with the foreign real interest rate.

$$
\begin{aligned}
& E_{t} r_{t, t+1}=i_{t, t+1}-E_{t} \pi_{t, t+1} \\
& E_{t} r_{t, t+1}=i_{t, t+1}^{*}-E_{t}\left(s_{t+1}-s_{t}\right)-\left[E_{t} \pi_{t, t+1}^{*}-E_{t}\left(s_{t+1}-s_{t}\right)\right] \\
& E_{t} r_{t, t+1}=i_{t, t+1}^{*}-E_{t} \pi_{t, t+1}^{*} \\
& E_{t} r_{t, t+1}=E_{t} r_{t, t+1}^{*}
\end{aligned}
$$

